\title{
Article \\ Evaluation of Wear of Disc Brake Friction Linings and the Variability of the Friction Coefficient on the Basis of Vibroacoustic Signals
}

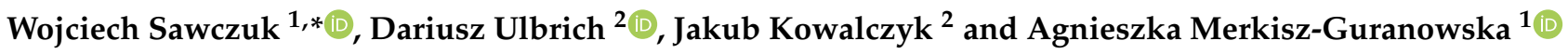 \\ 1 Institute of Transport, Faculty of Transport and Civil Engineering, Poznan University of Technology, \\ 60-965 Poznan, Poland; agnieszka.merkisz-guranowska@put.poznan.pl \\ 2 Institute of Machines and Motor Vehicles, Faculty of Transport and Civil Engineering, \\ Poznan University of Technology, 60-965 Poznan, Poland; dariusz.ulbrich@put.poznan.pl (D.U.); \\ jakub.kowalczyk@put.poznan.pl (J.K.) \\ * Correspondence: wojciech.sawczuk@put.poznan.pl; Tel.: +48-61-224-4510
}

Citation: Sawczuk, W.; Ulbrich, D.; Kowalczyk, J.; Merkisz-Guranowska, A. Evaluation of Wear of Disc Brake Friction Linings and the Variability of the Friction Coefficient on the Basis of Vibroacoustic Signals. Sensors 2021, 21, 5927. https://doi.org/10.3390/ s21175927

Received: 22 July 2021

Accepted: 31 August 2021

Published: 3 September 2021

Publisher's Note: MDPI stays neutral with regard to jurisdictional claims in published maps and institutional affiliations.

Copyright: (c) 2021 by the authors. Licensee MDPI, Basel, Switzerland. This article is an open access article distributed under the terms and conditions of the Creative Commons Attribution (CC BY) license (https:// creativecommons.org/licenses/by/ $4.0 /)$.

\begin{abstract}
The article presents the results of friction and vibroacoustic tests of a railway disc brake carried out on a brake stand. The vibration signal generated by the friction linings provides information on their wear and offers evaluation of the braking process, i.e., changes in the average friction coefficient. The algorithm presents simple regression linear and non-linear models for the thickness of the friction linings and the average coefficient of friction based on the effective value of vibration acceleration. The vibration acceleration signals were analyzed in the amplitude and frequency domains. In both cases, satisfactory values of the dynamics of changes above $6 \mathrm{~dB}$ were obtained. In the case of spectral analysis using a mid-band filter, more accurate models of the friction lining thickness and the average coefficient of friction were obtained. However, the spectral analysis does not allow the estimation of the lining thickness and the friction coefficient at low braking speeds, i.e., 50 and $80 \mathrm{~km} / \mathrm{h}$. The analysis of amplitudes leads to the determination of models in the entire braking speed range from 50 to $200 \mathrm{~km} / \mathrm{h}$, despite the lower accuracy compared to the model, based on the spectral analysis. The vibroacoustic literature presents methods of diagnosis of the wear of various machine elements such as bearings or friction linings, based on amplitude or frequency analysis of vibrations. These signal analysis methods have their limitations with regard to their scope of use and the accuracy of diagnosis. There are no cases of simultaneous use of different methods of analysis. This article presents the simultaneous application of the amplitude and frequency methods in the analysis of vibroacoustic signals generated by brake linings. Moreover, algorithms for assessing the wear of friction linings and the average coefficient of friction were presented. The algorithm enables determination of the time at which the friction linings should be replaced with new ones. The final algorithm analyzes the vibration acceleration signals using both amplitude analysis for low braking speeds, as well as spectral analysis for medium and high braking speeds.
\end{abstract}

Keywords: vibration; friction lining; friction coefficient; regression model

\section{Introduction}

Changes in the construction of disc brakes are related to the increase in train speed. The braking system absorbs and dissipates the vehicle's energy to the environment as heat during the braking process. The unfavorable processes during the braking of rail vehicles include vibroacoustic processes in the brake system (vibrations, noise), thermal processes occurring in the friction pair, and wear of the brake components. The above processes affect the deterioration of the acoustic environment, especially the comfort of passengers and the operating costs of rail vehicles. Vibroacoustic phenomena emitted by brake systems are considered very undesirable. The problem of vibrations in the brakes of railway and car vehicles has been recognised since the 1930s [1,2]. 
Vibroacoustic processes generated by braking systems are analyzed in three groups. The first group covers works on noise during the braking process; there are articles that attempt to recognize and identify the cause of noise [3-8], while other scientists are trying to model noise depending on the geometric features of the brake system, as well as the elements of the brake friction pair. In the second, less numerous group of publications on vibroacoustic processes in braking systems, there are works related to the use of vibrations of the braking system to assess the wear condition of brake friction elements [9,10]. In [11], the authors presented the possibility of using resonant vibrations in the assessment of wear of friction linings. These tests were preceded by a modal analysis of the braking system components in order to determine the resonance frequencies of these components. Then, the wear of the friction linings was assessed at these frequencies. The paper [12] presents the analysis of vibration acceleration signals in the frequency domain using band filters, from which the effective value of vibration accelerations was determined. The work [13] contains the results of the analysis in the amplitudes domain using known measures. For the purpose of the diagnosis of friction lining wear, the article analyzes such measures as the effective value of vibration acceleration ( $\left.A_{\text {RMS }}\right)$, the average value $\left(A_{A V E R A G E}\right)$, the root value (ASQUARE), and the peak value of the vibration acceleration (APEAK). From this analysis, two point measures were selected, i.e., $A_{\text {RMS }}$ and $A_{\text {AVERAGE }}$, which, due to the smallest relative error in diagnosis, are best suited for the price and estimation of the wear value of rail brake linings. The least numerous group are those dealing with the use of vibrations of the braking system also in the assessment of the braking process [14,15]. The work [16] is the first attempt to present the dependence of the friction coefficient on vibrations of friction linings, which in the future may be used in the evaluation of the braking process. It was demonstrated only in the example of three frequency characteristics from braking from the speeds of 120, 160 and $200 \mathrm{~km} / \mathrm{h}$.

Most of the models describing the vibrations of the braking system are based on the assumption that the increase in vibrations, as a phenomenon strongly dependent on many variables, is largely influenced by the variability of the friction coefficient between the brake lining and the brake disc throughout the braking process. Additionally, the susceptibility of the braking system, particularly brake linings, contributes to increase and to reduce the vibrations generated by the braking system. The first models assumed that the self-excited vibrations of the brake were related to a decrease in the friction coefficient and an increase in the sliding velocity (Figure 1). This is true for many friction materials, but for a limited range of speed changes, which was already described in the works [1,7].

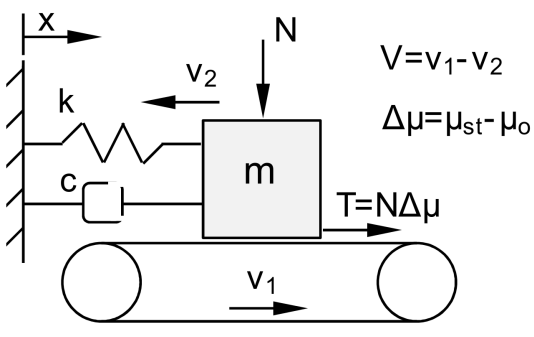

(a)

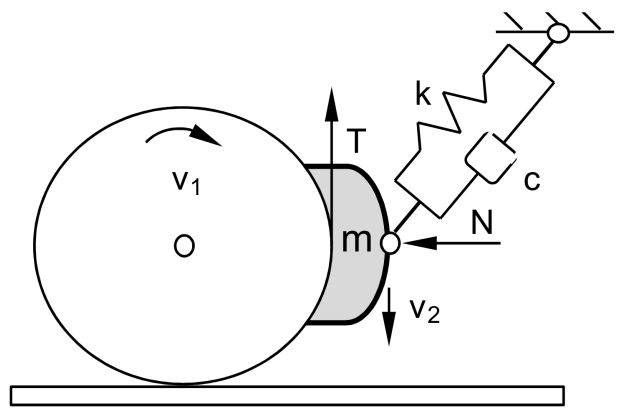

(b)

Figure 1. Brake system models: (a) Model of an elastic friction system on the example of a conveyor belt (stick-slip phenomenon), k-spring stiffness, c-viscous damping coefficient, $\mathrm{m}$-block mass, $\mathrm{N}$-pressure force on the conveyor belt, $\mathrm{T}$-friction, $\mathrm{V}$-relative speed, $\mathrm{v}_{1}$-conveyor belt speed, $\mathrm{v}_{2}$ pad speed, $\mu_{\text {st }}$-static friction coefficient, $\mu_{\mathrm{o}}$-kinetic friction coefficient, $x$-displacement; (b) Model of the actual brake system $1 \mathrm{Bg}$ in the railway block brake.

In 1961, Fosberry and Holubecki [17] found that in brake systems, vibrations caused by the cooperation of the pad-disc friction pair have a static friction coefficient $\mu_{\mathrm{st}}$ higher than the kinetic friction coefficient $\mu_{\mathrm{k}}$, or the kinetic friction coefficient decreases with increasing 
velocity v2. Similar conclusions were contained in the work of Sinclair [6] from 1955 and Earles [18]. Other researchers, such as Mills, Bowden and Leben [19] conducted research on elastic friction systems, comparing them to stick-slip motion. The main conclusion from this research was that the vibroacoustic events have not been fully established. The most likely explanation of these phenomena is stick-slip motion occurring in the frictional coupling. The energy source of this motion is the change of the friction coefficient as a function of velocity [4]. However, the stick-slip model does not take into account the effect of system damping.

Spurr in [20] proposed the term sprag-slip to describe vibroacoustic phenomena in brake systems. According to this term, the vibroacoustic phenomena generated by brake systems result from the contact of the friction material with the brake disc. The friction force in such a system can be much greater than the force in a perfectly rigid system. In the real braking system, due to elastic deformations and displacement of elements, there is a cyclical momentary decrease and increase in the value of the friction force. The model of the sprag-slip phenomenon of a stiff bar fixed at point $\mathrm{O}$ and loaded with an external force $\mathrm{L}$ acting on the other end of the bar at the point of contact with the stiff displacing surface is shown in Figure 2a.

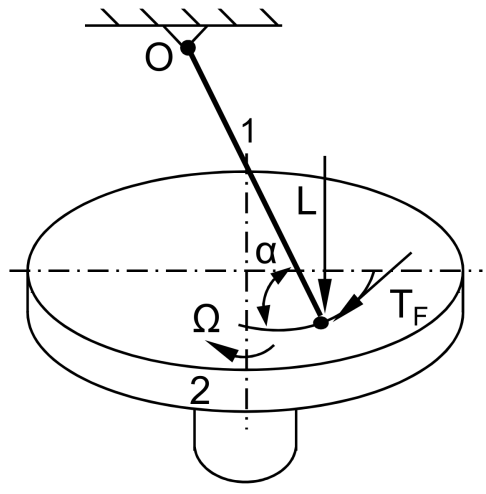

(a)

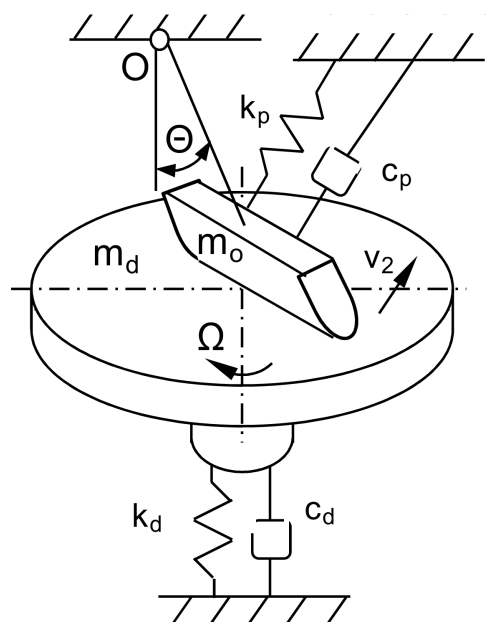

(b)

Figure 2. Models of brake systems: (a) Model of the sprag-slip phenomenon according to Spurr, 1 -stiff rod rotating at point $\mathrm{O}, 2$-stiff rotating disc; (b) Model of the friction disc-slider system on the Jarvis and Earles angle cantilever, $\alpha$-slope angle of cantilever in the horizontal plane, Zbracket width in $\mathrm{m}, \mathrm{R}$ - bracket rotation radius in $\mathrm{m}, \Omega$ - plate rotation speed in rpm, $\theta$-cantilever slope angle in the vertical plane, $\mathrm{v}_{2}$ - slider linear speed in $\mathrm{m} / \mathrm{s}, \mathrm{m}_{\mathrm{o}}$-weight of the cantilever in $\mathrm{kg}$, $\mathrm{m}_{\mathrm{d}}$-weight of the panel in $\mathrm{kg}, \mathrm{c}_{\mathrm{p}}$ - cantilever damping, $\mathrm{k}_{\mathrm{p}}$ - cantilever stiffness, $\mathrm{c}_{\mathrm{d}}$ - disc damping, $k_{d}$ 一 disc stiffness.

If $T_{F}={ }_{\mu k} N$, the equilibrium of the system will be maintained on the basis of Equation (1) presented in [17]:

$$
T_{F}=\frac{\mu_{k} L}{1-\mu_{k} \tan (\alpha)}
$$

If the angle of inclination of the stiff rod $\alpha$ tends to the value of $\tan ^{-1}\left(1 / \mu_{k}\right)$, then the friction force $T_{F}$ will approach infinity. Spurr referred this particular case as spragging. This model was then refined by Jarvis and Earles, as shown in Figure 2b [7].

The brake instability condition was defined by the relationship [7]:

$$
\frac{1}{2}\left(\mu_{k}-\tan \theta \sin \right) 2 \theta>\frac{C_{p}}{C_{d}}
$$


It was the first attempt of theoretical presentation of the sprag-slip phenomenon. A rotating plate with an attached cantilever was used to explain the vibroacoustic phenomena. Later models based on the considerations of Jarvis, Mills and Earles were shown. These models were more complicated, with more and more degrees of freedom and several friction models. Another model was proposed by North, and then by Millner. It was a model of the binary flutter, which is more similar to a disc brake $[7,10]$. The mechanism of vibrations in this case is similar to vibrations during the flapping of wings in airplanes, i.e., flutter. The disc brake track has been replaced with a rigid straight beam with two degrees of freedom. Crolla and Lang found that this and other models do not fully reflect the actual brake construction. However, thanks to their research, it is possible to obtain a qualitative hint at the design process. In addition, solutions that eliminate some classes of brake vibrations and the emitted noise can be designed [7].

Lang and Smales in [3] discerned two types of vibroacoustic events coming from braking systems. This distinction also applies today. The phenomena occur at low frequenciesfrom 1 to $5 \mathrm{kHz}$ and at high frequencies, above $5 \mathrm{kHz}$. The Lang and Smales model in the low frequency range allows for the treatment of the friction lining as a rigid body. However, at high frequencies, the deformation of the friction elements should be additionally taken into account. The assumption of a rigid body as a friction material was also taken into consideration by Brooks [10] and Milner [21], as well as Rudolph and Popp [5,22]. In addition, the susceptibility of the brake system components, in particular the brake friction linings, increases the wear of the friction material (its emission to the environment-a highly unfavorable phenomenon) and decreases vibrations generated by the brake system (a favorable phenomenon). The collected results from the operation of the braking system allow for its reliability analysis $[23,24]$.

\section{Materials and Methods}

Determination of selected frictional and vibroacoustic characteristics, depending on the parameters of the braking process, was carried out. During the tests, the input parameters were intentionally and in a specific way changed, i.e., friction linings of different thickness, braking speed, and their influence on the changes in the output parameters were observed. The initial parameters were the instantaneous vibration accelerations recorded on the mounts with friction linings. In particular, attention was paid to the influence of the condition of the braking system understood as the wear of friction linings (linings of different thickness) on the frictional characteristics (average coefficient of friction as a function of speed) and vibroacoustic characteristics (effective value and average of vibration acceleration determined during braking from a given speed on the lining at a specific thickness). The tests were carried out on the inertia brake stand, shown in Figure 3. The test stand allows for testing the rail block and disc brake, reflecting the actual conditions that occur during braking of the rail vehicle.

The tests were carried out on a ventilated brake disc with dimensions of $\varnothing 610 \times 110 \mathrm{~mm}$, made of gray cast iron. The brake disc was prepared for tests in accordance with the EN 14535-1:2005 standard [25]. The linings (Frimatrail Frenoplast S.A., Wołomin, Poland), in accordance with the manufacturer's procedure and the requirements contained in [26], were made of thermohardening resin, synthetic elastomer, metal and organic fibers, and friction modifiers.

Three sets of linings were used for the stand tests. One new set of linings (4 pieces) had a thickness of $G_{1}=35 \mathrm{~mm}$ and two sets used up to a thickness of $G_{2}=25 \mathrm{~mm}$ and $G_{3}=15 \mathrm{~mm}$. The friction lining weights were, respectively, $\mathrm{m}_{\mathrm{G} 1}=1.75 \mathrm{~kg}$ (new lining), $\mathrm{m}_{\mathrm{G} 2}=1.45 \mathrm{~kg}$ (lining worn to a thickness of $25 \mathrm{~mm}$ ), and $\mathrm{m}_{\mathrm{G} 3}=1.02 \mathrm{~kg}$ (lining worn to a thickness of $15 \mathrm{~mm}$ ). The vibroacoustic tests were carried out in parallel with the frictional (tribological) tests. One vibration transducer was attached to the brake system (right and left) as is shown in Figure $4 a, b$. The vibration transducers were bolted to the brake carrier plates to increase the vibration measurement range. The input quantities were the simulated braking initiation speed $\mathrm{v}_{\mathrm{o}}$, the brake pad pressure on the brake disc $\mathrm{N}$, the brake mass $\mathrm{M}$ and the friction 
lining thickness $G$. The output signals were the instantaneous tangential force $F_{t}$ related to the braking radius $r_{h}$, the instantaneous pressure force on the brake disc $F_{b}$, as well as the instantaneous acceleration value of vibrations a. Thanks to this, it was possible to observe the influence of changing the input parameters on the obtained output signal.

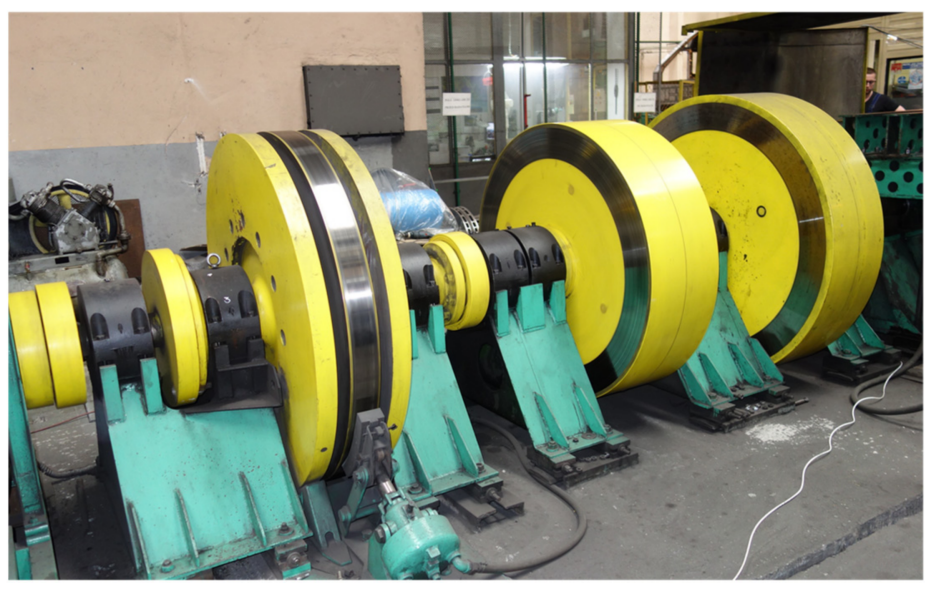

(a)

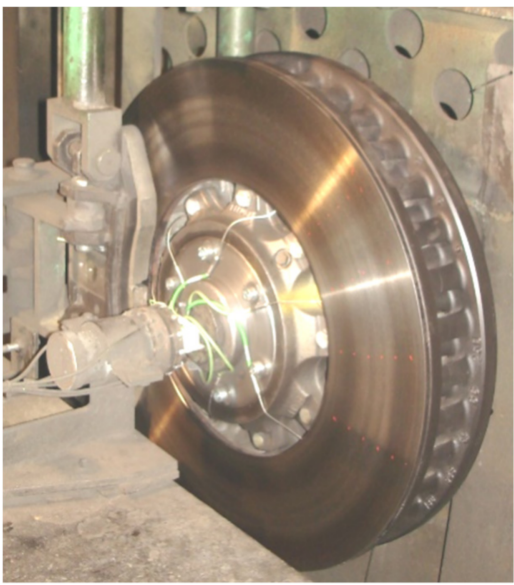

(b)

Figure 3. Stand for testing railway disc brakes: (a) driving part of the brake stand with rotating masses, (b) brake disc type $610 \times 110 \mathrm{~mm}$ mounted on the brake stand.

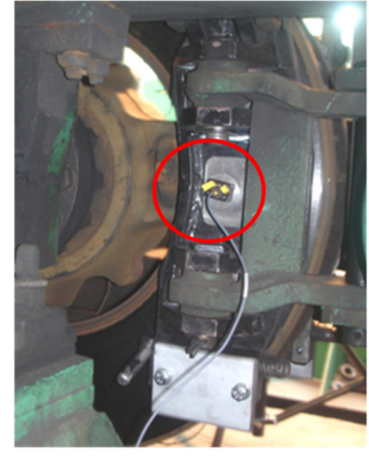

(a)

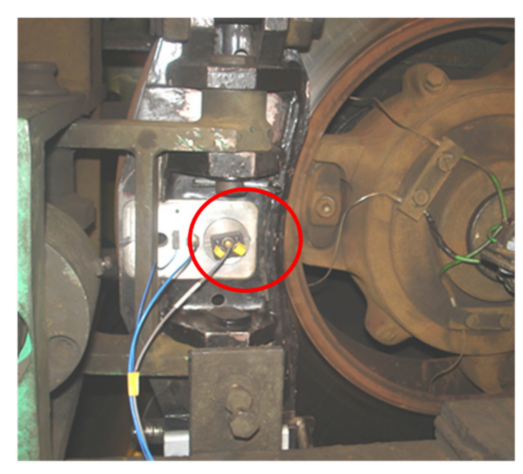

(b)

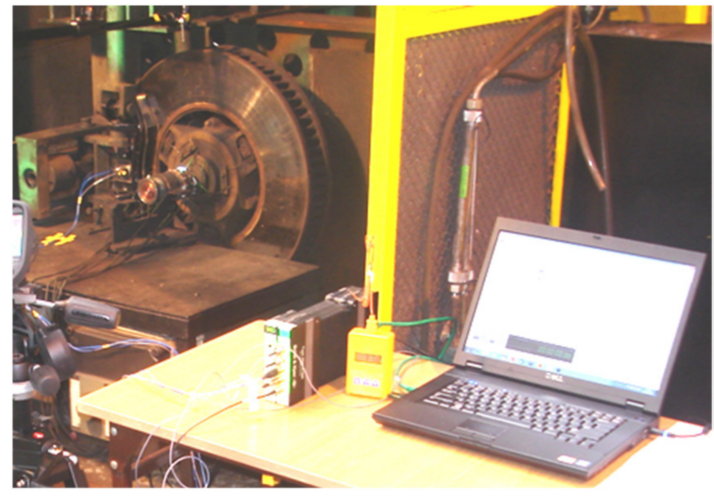

(c)

Figure 4. The tested brake disc mounted on the brake stand for testing railway disc brakes: (a) view of the left friction pair-brake disc with lining and attached vibration transducer, (b) view of the right brake holder and attached vibration transducer, (c) view of the stand with vibration measurement equipment.

Figure $4 \mathrm{c}$ shows the brake stand with the measuring equipment. The HBM type sensor was used to measure the force and the vibrations were measured by the B\&K $4504 \mathrm{~A}$ transducers.

Vibration transducers should be located close to the place generating the vibroacoustic signal (signal from the brake friction pair) and in a place easily accessible for the measurement. The vibration accelerations were measured in the perpendicular direction to the surface of the brake disc, based on the experience of other researchers presented in the works [27].

Figure 5 shows a diagram of the measuring system used in the brake stand, extended with the measurement of vibration acceleration. 


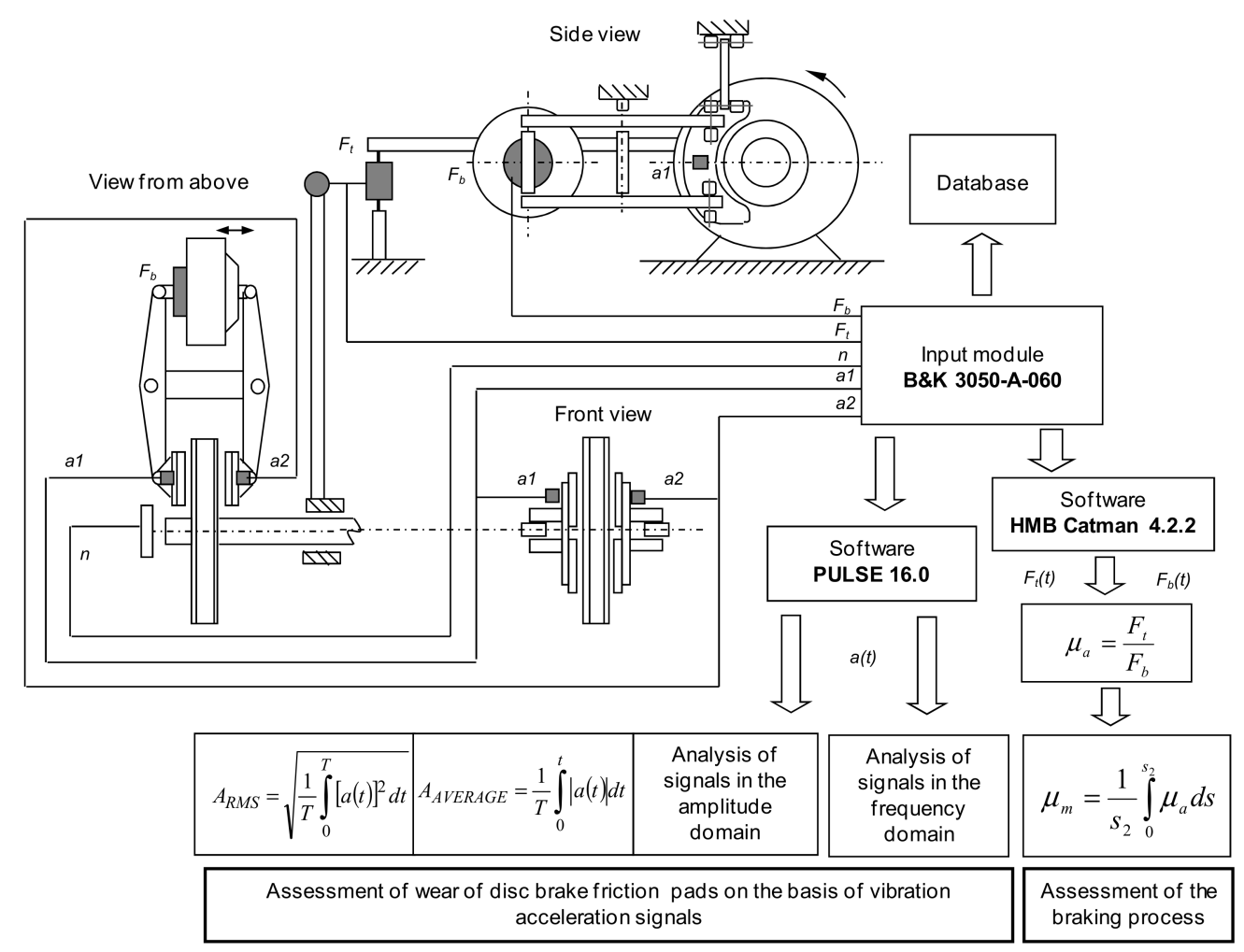

Figure 5. Diagram of the measuring system used during vibroacoustic stand tests.

The linear frequency response of the converters was $13 \mathrm{kHz}$. During the diagnostic tests, signals in the $0.1 \mathrm{~Hz}$ to $9 \mathrm{kHz}$ band were recorded. The sampling frequency was set to $32 \mathrm{kHz}$. This means that the band analyzed according to the Nyquist relationship was $16 \mathrm{kHz}$.

\section{Results}

The obtained signals of vibration acceleration generated by the braking system during braking were analyzed in the time domain. Figure 6 shows the changes of the instantaneous vibration accelerations recorded during slope braking. Then, the signals for each of the claddings were analyzed in the domain of amplitudes and frequency.

Based on the changes presented in Figure 6, it can be concluded that the wear of the friction material affects the increase in the amplitude of vibration acceleration from the holder with friction linings. Therefore, there is a dependence of the vibrations measured on the brake holder on the condition of the brake system (lining wear). Determining the dependence of the average coefficient of friction on the vibrations generated by the braking system required measurements for all considered braking speeds and recording of the instantaneous vibration acceleration of the brake holders with linings (for both sides of the brake disc).

For the analysis of vibration signals in the amplitude domain, measures are often used, which characterize a vibration process with one value [28]. Then, especially in vibroacoustic diagnostics (WA), it is possible to determine changes in the WA signal resulting from a change in the technical condition of the tested object. There are many publications in the literature presenting the use of vibroacoustic diagnostics (in some cases in combination with thermal imaging diagnostics) in automotive, railroad or air vehicles [19,29-36]. 


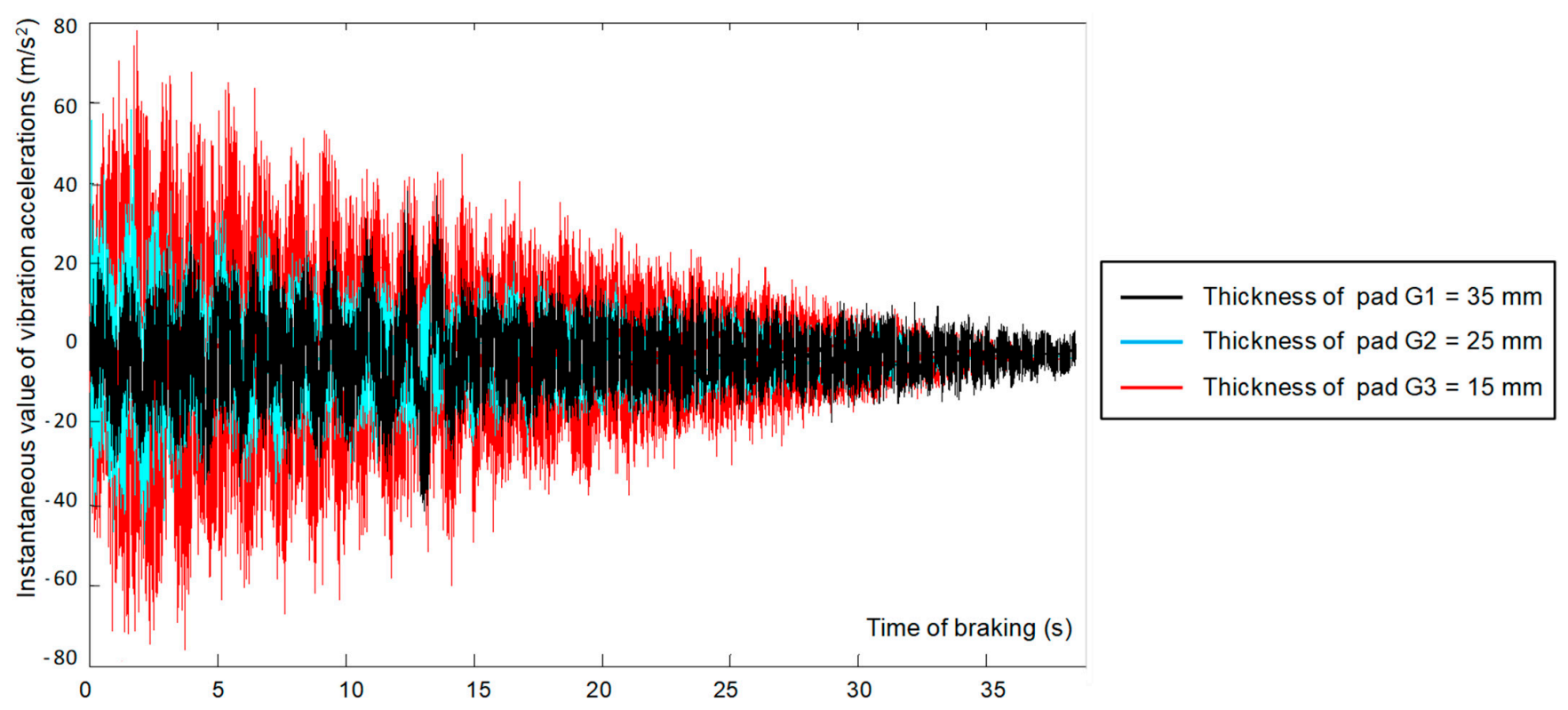

Figure 6. Signal of vibration accelerations registered on lining cladding for different thicknesses of linings during braking to stop (speed at beginning of braking $v=120 \mathrm{~km} / \mathrm{h}$ ).

The measures used in vibroacoustic diagnostics are divided into dimensional and non-dimensional points [28]. The measures used to diagnose the wear of the friction linings of the railway disc brake were as follows:

- average amplitude, presented with the relationship:

$$
\mathrm{A}_{\text {AVERAGE }}=\frac{1}{T} \int_{0}^{T}|s(t)| d t
$$

where: $T$-averaging time, $s(t)$-instantaneous value of the amplitude of displacements, velocities or accelerations of vibrations;

- effective amplitude, described by the equation:

$$
\mathrm{A}_{\mathrm{RMS}}=\sqrt{\frac{1}{T} \int_{0}^{T}[s(t)]^{2} d t}
$$

In the vibroacoustic tests it was observed that for the measurement of the vibration accelerations on both sides of the brake disc during braking, different values of the signals were recorded. The vibrations measured on the brake holder from the side of the brake cylinder are characterized by a higher value of vibration accelerations than those measured from the side of the piston rod brake. The various values were obtained, despite the fact that the lever mechanism is characterized by a symmetrical construction of the right and left sides. A detailed explanation of this phenomenon is described in [37]. For further analysis, the results measured on the holder from the side of the brake cylinder were used. Before calculating measures from vibration acceleration signals, a time selection was made in the MATLAB program. As a result of this analysis, the part related only to the braking process was separated from the entire recorded signal in order to obtain the required dynamics of changes, important for diagnostic purposes. The dependence of the friction lining thickness on the selected measures was determined by the dynamics of changes for a given parameter, which is shown in the following relationship [38]:

$$
D_{1(2)}=20 \log _{10}\left(\frac{A_{2}}{A_{1}}\right)
$$


where: $A_{1}$-value of the measure determined for the $G_{1}$ cladding, $A_{2}$ 一value of the measure determined for the $G_{3}$ or $G_{2}$ cladding.

In terms of frictional characteristics, the tangential force $F_{t}$ and the pressure force on the brake disc $F_{b}$ were measured on the brake stand in order to determine the instantaneous coefficient of friction $\mu_{a}$. Then, the average coefficient of friction was calculated according to the relationship where $s$ is the measured braking distance [26].

$$
\mu_{m}=\frac{1}{s_{2}} \int_{0}^{s_{2}} \mu \times d s
$$

Figure 7 shows the dependence of the average coefficient of friction $\mu_{m}$ depending on the braking start speed, with the brake pad pressure to the disc equaling $\mathrm{N}=25 \mathrm{kN}$ and the brake mass being $\mathrm{M}=5.7 \mathrm{t}$.

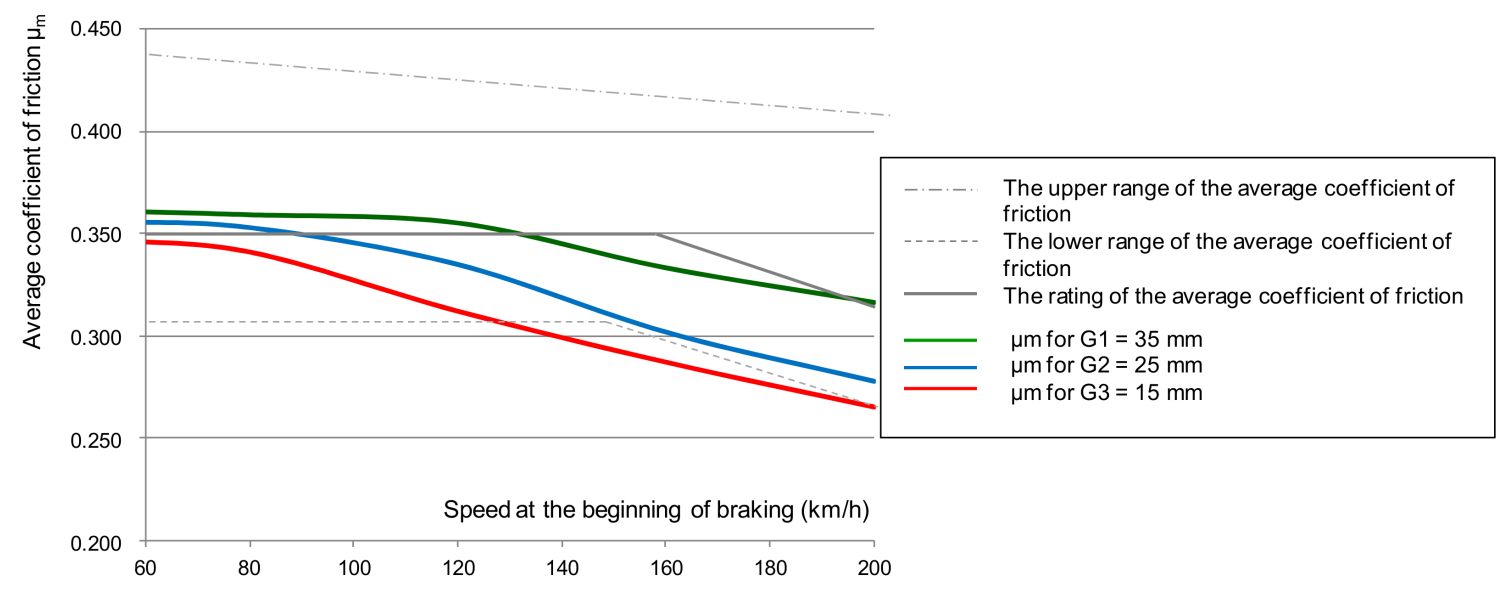

Figure 7. Dependence of the average coefficient of friction $\mu_{m}$ on the set braking start speed at $\mathrm{N}=25 \mathrm{kN}$ and $\mathrm{M}=5.7 \mathrm{t}$ at different friction lining thicknesses.

Based on the changes shown in Figure 7, it should be stated that with the change in the thickness of the friction linings (with the increase in the wear of the friction linings), the value of the average coefficient of friction decreases. This relationship was observed for all the analyzed braking speeds (from 50 to $200 \mathrm{~km} / \mathrm{h}$ ).

\section{Regression Model of Friction Lining Wear and $\mu_{m}$ Coefficient Variability Based on the Analysis of Vibration Acceleration Signals in the Amplitude Domain}

The literature contains the results of research $[39,40]$ on the use of vibroacoustics to diagnose the wear of brake friction linings in both road and rail vehicles. Then, such measures as the effective value of $A_{R M S}$ vibration accelerations described by the relationship (3), or the average value $A_{\text {Average }}$ (relationship (4)), are used. In the diagnostics of the braking system, the above-mentioned measures have the highest value of the dynamics of changes in the diagnostic parameter. However, in the scope of modeling the value of the average coefficient of friction of a disc brake, it should first be shown that there is a dependence of changes in the value of the vibration signal on the condition of the friction linings (their wear). Then, it would be possible to use these relationships when modeling the friction coefficient, which strongly depends on the wear of the friction material [41,42]. Figure 8 shows the dependence of the effective and mean value of vibration accelerations on braking at speeds of 50, 80,120, 160 and $200 \mathrm{~km} / \mathrm{h}$. The results of the VA tests were adjusted in the form of the effective value and the mean value of vibration accelerations for the analyzed speeds using the least squares method. On this basis, regression models with a visible coefficient of determination $R^{2}$ were determined. Each point on the graph in Figure 8 is the average of eight measurements. The number of repetitions was based on previous tests carried out on a 40-braking test. These vibroacoustic tests were carried out 
on the vibrations recorded on the linings on the right and left side of the brake disc. During the preliminary tests, the mean value and variance (standard deviation) were calculated for each successive braking. Then, the coefficient of variation was calculated. It has been observed that the value of the coefficient of variation is below $10 \%$ with the braking. Then, the stationarity and ergodicity of the recorded vibration acceleration signals were checked. The study of the nature of the signals influenced the establishment of the later methodology of the main research.

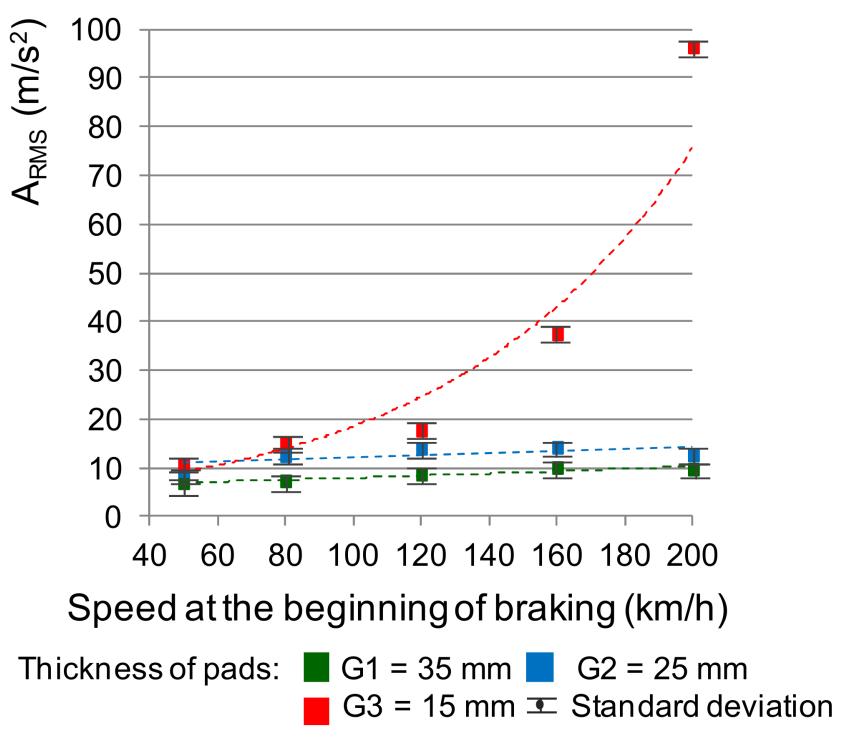

(a)

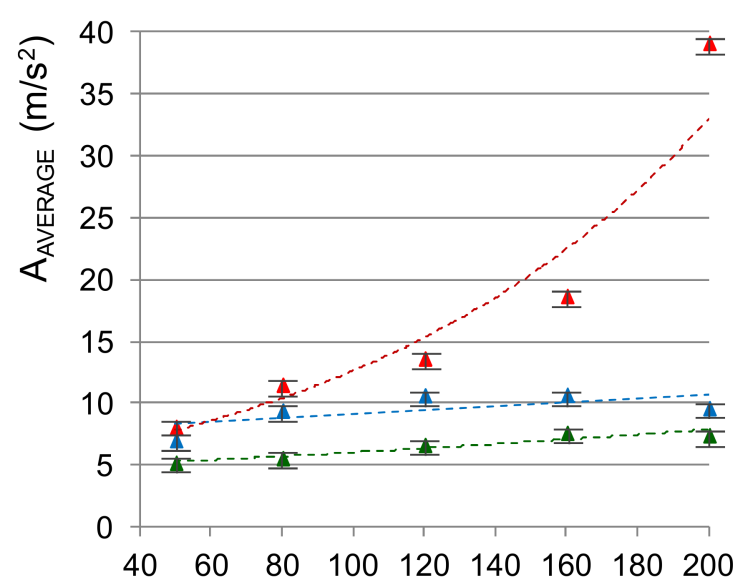

Speed at the beginning of braking $(\mathrm{km} / \mathrm{h})$

(b)

Figure 8. Dependence of the measure of vibration acceleration on the speed at the beginning of braking and the wear of the friction linings: (a) ARMS effective value, (b) average value $A_{\text {Average }}$.

A diagnostic regression model was used in the analysis of vibroacoustic signals. This model assumes that the condition parameters (lining wear) influence the signal parameters. One-dimensional linear models and one-dimensional non-linear models were used. The choice of the regression model depended on the obtained coefficient of determination $\mathrm{R}^{2}$. For the test points, the fit was checked with a linear function and various non-linear functions. The selection of the function depended on the highest value of the $\mathrm{R}^{2}$ determination coefficient. Changes in the values of measures $\left(A_{R M S}\right.$ and $\left.A_{A V E R A G E}\right)$ as a function of speed at the beginning of braking for different friction lining thicknesses were described by the following linear and non-linear functions:

$$
\begin{gathered}
A_{\mathrm{RMS}}=0.0219 \times v_{0}+5.8382 ; \text { for } G_{1}=35 \mathrm{~mm} \\
A_{\mathrm{RMS}}=0.0202 \times v_{0}+10.034 ; \text { for } G_{2}=25 \mathrm{~mm} \\
A_{\mathrm{RMS}}=4.517 e^{0.0141 v_{0}} ; \text { for } G_{3}=15 \mathrm{~mm} \\
A_{\mathrm{AVERAGE}}=0.017 \times v_{0}+4.3879 ; \text { for } G_{1}=35 \mathrm{~mm} \\
A_{\mathrm{AVERAGE}}=0.0162 \times v_{0}+7.4859 ; \text { for } G_{2}=25 \mathrm{~mm} \\
A_{\mathrm{AVERAGE}}=4.8282 e^{0.0096 v_{0}} ; \text { for } G_{3}=15 \mathrm{~mm}
\end{gathered}
$$

Table 1 shows the values of measures determined from the braking process for different speeds at the beginning of braking along with the dynamics of changes. 
Table 1. The values of the measures of the vibration acceleration of the friction linings depending on the speed of braking and the wear of the friction linings, along with the dynamics of changes.

\begin{tabular}{|c|c|c|c|c|}
\hline \multirow[b]{2}{*}{ Measure } & \multicolumn{3}{|c|}{ Values of Measure $\mathrm{m} / \mathrm{s}^{2}$} & \multirow{2}{*}{$\begin{array}{c}\text { Dynamics of } \\
\text { Change dB }\end{array}$} \\
\hline & $\begin{array}{l}\text { Cladding Thickness } \\
\mathrm{G}_{1}=35 \mathrm{~mm}\end{array}$ & $\begin{array}{l}\text { Cladding Thickness } \\
\mathrm{G}_{2}=25 \mathrm{~mm}\end{array}$ & $\begin{array}{l}\text { Cladding Thickness } \\
\mathrm{G}_{3}=15 \mathrm{~mm}\end{array}$ & \\
\hline \multicolumn{5}{|c|}{ Braking start at $v_{0}=50 \mathrm{~km} / \mathrm{h}$} \\
\hline$A_{\text {RMS }}$ & 6.88 & 9.36 & 10.63 & 3.78 \\
\hline $\mathrm{A}_{\mathrm{AVERAGE}}$ & 5.18 & 7.01 & 8.07 & 3.86 \\
\hline \multicolumn{5}{|c|}{ Braking start at $v_{0}=80 \mathrm{~km} / \mathrm{h}$} \\
\hline $\mathrm{A}_{\mathrm{RMS}}$ & 7.29 & 12.47 & 15.05 & 6.29 \\
\hline $\mathrm{A}_{\mathrm{AVERAGE}}$ & 5.55 & 9.39 & 11.48 & 6.32 \\
\hline \multicolumn{5}{|c|}{ Braking start at $v_{0}=120 \mathrm{~km} / \mathrm{h}$} \\
\hline $\mathrm{A}_{\mathrm{RMS}}$ & 8.65 & 13.95 & 17.68 & 6.21 \\
\hline $\mathrm{A}_{\text {AVERAGE }}$ & 6.61 & 10.62 & 13.60 & 6.26 \\
\hline \multicolumn{5}{|c|}{ Braking start at $v_{0}=160 \mathrm{~km} / \mathrm{h}$} \\
\hline$A_{\text {RMS }}$ & 10.03 & 14.17 & 37.46 & 11.4 \\
\hline $\mathrm{A}_{\mathrm{AVERAGE}}$ & 7.59 & 10.67 & 18.66 & 7.8 \\
\hline \multicolumn{5}{|c|}{ Braking start at $v_{0}=200 \mathrm{~km} / \mathrm{h}$} \\
\hline $\mathrm{A}_{\mathrm{RMS}}$ & 9.68 & 12.57 & 96.31 & 19.7 \\
\hline $\mathrm{A}_{\mathrm{AVERAGE}}$ & 7.40 & 9.59 & 39.12 & 14.5 \\
\hline
\end{tabular}

The analysis of the test results showed that there is a dependence of the measurement values on the wear of the friction linings by measuring the vibrations on the brake holder. Only for low speeds (up to $50 \mathrm{~km} / \mathrm{h}$ ), the dynamics of changes of the most worn lining up to a thickness of $15 \mathrm{~mm}$ does not reach $6 \mathrm{~dB}$. For the remaining speeds at the beginning of braking $80-200 \mathrm{~km} / \mathrm{h}$, the dynamics of changes is 6-19 dB. Due to the dynamic nature of the braking process, especially at high speeds, vibrations generated by the brake system provide information about the wear of the friction elements. On the other hand, the dependence of the friction coefficient on the speed and condition of the friction material will make it possible to evaluate the braking process (the value of the average coefficient of friction). To assess the wear of the friction linings, the inverse function to the approximating functions described by the relations (7)-(12) should be used; allowing estimation of the thickness of the friction linings on the basis of the measurement values. Figure 9 presents the dependence of the friction lining thickness on the average $\mathrm{A}_{\mathrm{AVERAGE}}$ value. In the case of the RMS effective value, similar characteristics were obtained.

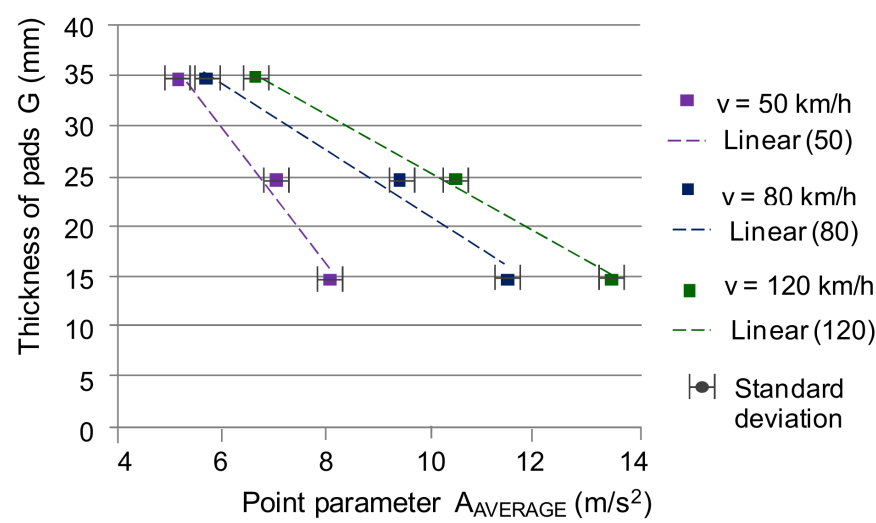

(a)

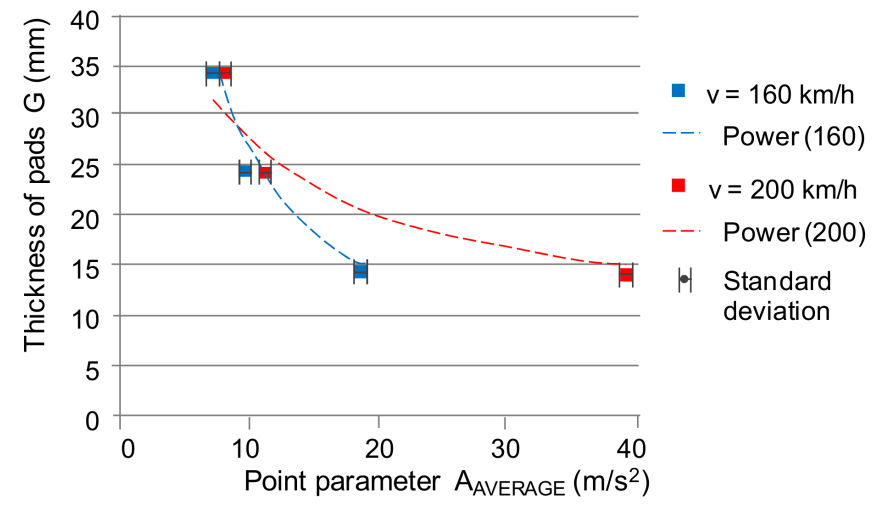

(b)

Figure 9. Dependence of the friction lining thickness on the effective value of vibration acceleration for the braking speed: (a) $v=50,80$ and $120 \mathrm{~km} / \mathrm{h},(\mathbf{b}) v=160$ and $200 \mathrm{~km} / \mathrm{h}$. 
The dependence of the friction lining thickness on the value of the measures due to the highest value of the coefficient of determination $\mathrm{R}^{2}$ was approximated by the following linear functions for the beginning of braking at speeds from 50 to $120 \mathrm{~km} / \mathrm{h}$, and power functions for speeds of 160 and $200 \mathrm{~km} / \mathrm{h}$ :

$$
\begin{gathered}
\mathrm{G}=-6.7505 \times A_{\text {AVERAGE }}+70.583 ; \text { for } v=50 \mathrm{~km} / \mathrm{h} \\
\mathrm{G}=-3.2772 \times A_{\text {AVERAGE }}+53.854 ; \text { for } v=80 \mathrm{~km} / \mathrm{h} \\
\mathrm{G}=-2.8412 \times A_{\text {AVERAGE }}+54.203 ; \text { for } v=120 \mathrm{~km} / \mathrm{h} \\
\mathrm{G}=233.72 \times A_{\text {AVERAGE }}-0.94 ; \text { for } v=160 \mathrm{~km} / \mathrm{h} \\
\mathrm{G}=79.597 \times A_{\text {AVERAGE }}-0.46 ; \text { for } v=200 \mathrm{~km} / \mathrm{h}
\end{gathered}
$$

Based on the dependence (6) of the value of the average coefficient of friction obtained from the tests, the characteristics of changes in the average friction coefficient as a function of speed and wear of the friction material were determined (Figure 10).

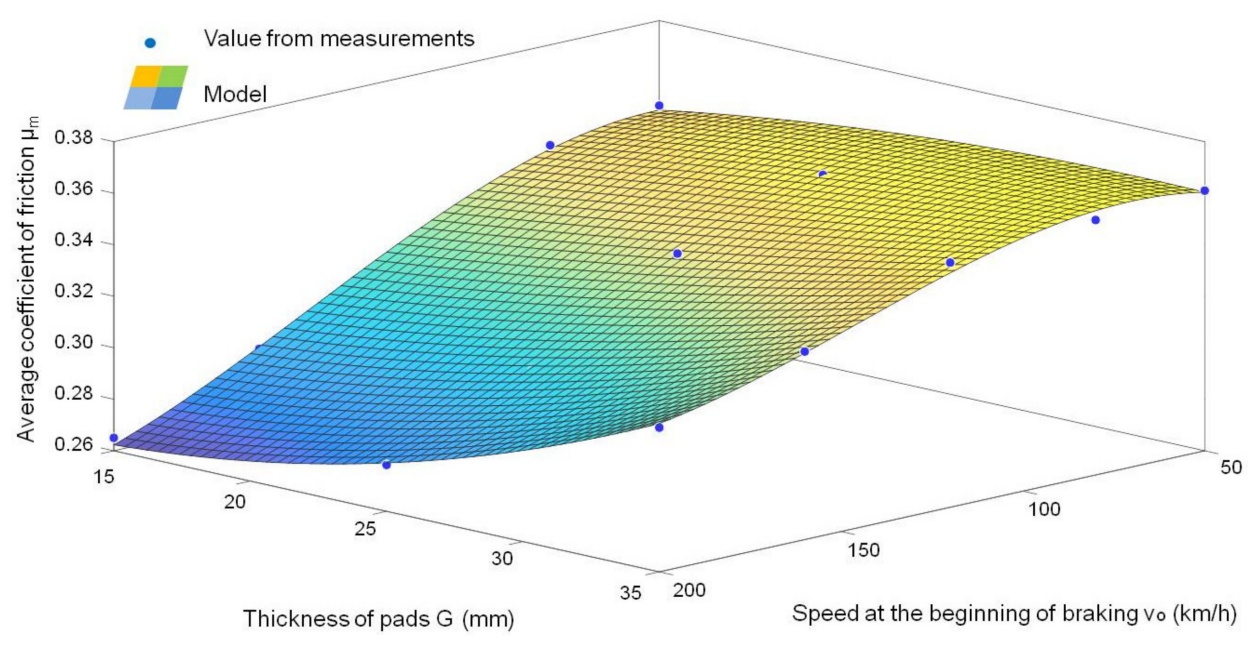

Figure 10. Dependence of the average coefficient of friction $\mu_{\mathrm{m}}$ on the braking speed for $\mathrm{N}=25 \mathrm{kN}$, $\mathrm{M}=5.7 \mathrm{t}$ and three friction lining thicknesses.

It can be concluded that the value of the average coefficient of friction decreases with the increase in wear of the friction linings (reduction of their thickness) and the increase in speed at the beginning of braking. The regression model of the value of the average coefficient of friction as a function of the speed at the beginning of braking and the thickness of the friction linings shows the relationship:

$$
\mu_{m}=\lambda_{1} v_{0}+\lambda_{2} G+\lambda_{3} v_{0}^{2}+\lambda_{4} v_{0} G+\lambda_{5} G^{2}+\lambda_{6} v_{0}^{3}+\lambda_{7} G v_{0}^{2}+\lambda_{8} v_{0} G^{2}+\lambda_{0}
$$

The final form of the regression model of the average coefficient of friction, depending on $v_{o}$ and $G$ after verification of the parameters of the multiple regression model, is represented by the relationship:

$$
\mu_{m}=\lambda_{1} v_{0}+\lambda_{2} G+\lambda_{3} v_{0}^{2}+\lambda_{4} v_{0} G+\lambda_{5} G^{2}+\lambda_{6} v_{0}^{3}+\lambda_{7} G v_{0}^{2}+\lambda_{8} v_{0} G^{2}
$$

Table 2 presents the values of the multiple regression function coefficients with the coefficient of determination $\mathrm{R}^{2}$ for the $\mu_{m}$ model before and after the verification of the model parameters. 
Table 2. Regression function coefficients with $\mathrm{R}^{2}$ fitting for the $\mu_{m}$ model.

\begin{tabular}{ccccc}
\hline \multicolumn{3}{c}{ Before Verification } & \multicolumn{2}{c}{ After Verification } \\
\hline \multirow{2}{*}{ Coefficient } & $\begin{array}{c}\text { Coefficient } \\
\text { Value }\end{array}$ & Value F & $\begin{array}{c}\text { Coefficient } \\
\text { Value }\end{array}$ & Value F * \\
& 0.00093858 & 0.01225 & 0.001393 & 0.001667 \\
$\lambda_{1}$ & 0.0043017 & 0.004541 & 0.005225 & 0.001726 \\
$\lambda_{2}$ & $-1.035 \times 10^{-5}$ & 0.00921 & $-1.2173 \times 10^{-5}$ & 0.005887 \\
$\lambda_{3}$ & $-2.202 \times 10^{-5}$ & 0.06318 & $-4.0207 \times 10^{-5}$ & 0.004797 \\
$\lambda_{4}$ & -0.0001027 & 0.005457 & -0.0001027 & 0.002679 \\
$\lambda_{5}$ & $2.778 \times 10^{-8}$ & 0.009771 & $2.7788 \times 10^{-8}$ & 0.01291 \\
$\lambda_{6}$ & $-7.283 \times 10^{-8}$ & 0.08624 & $1.0718 \times 10^{-6}$ & 0.001060 \\
$\lambda_{7}$ & $1.072 \times 10^{-6}$ & 0.001620 & & \\
$\lambda_{8}$ & 0.2885 & $4.9607 \times 10^{-24}$ & 0.2654 & $3.3132 \times 10^{-26}$ \\
$\lambda_{0}$ & 0.996 & $1.04 \times 10^{-7} *$ & 0.994 & $2.52 \times 10^{-8} *$ \\
$\mathrm{R}^{2}$ & & & &
\end{tabular}

* significance for a particular regression coefficient.

The regression model of the variability of the average friction coefficient (after verification of the model coefficients), described with the relationship (19), is based on two variables: the speed of the beginning of braking and the thickness of the friction linings. However, to estimate the value of the average coefficient of friction taking into account the vibrations of the friction linings, a different model was used (two functions model). The relationship between the thickness of the friction linings and the average $A_{A V E R A G E}$ value of the acceleration of the linings vibration and the dependence of $\mu_{m}$ on the thickness of the friction linings was used. The dependence of $\mu_{m}$ on the thickness of the friction linings was presented in Figure 11.

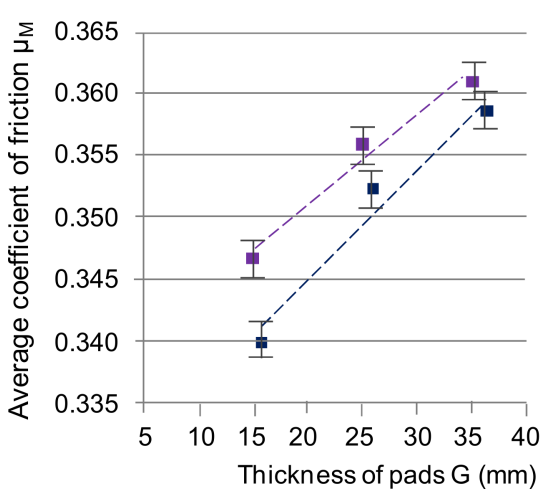

(a)

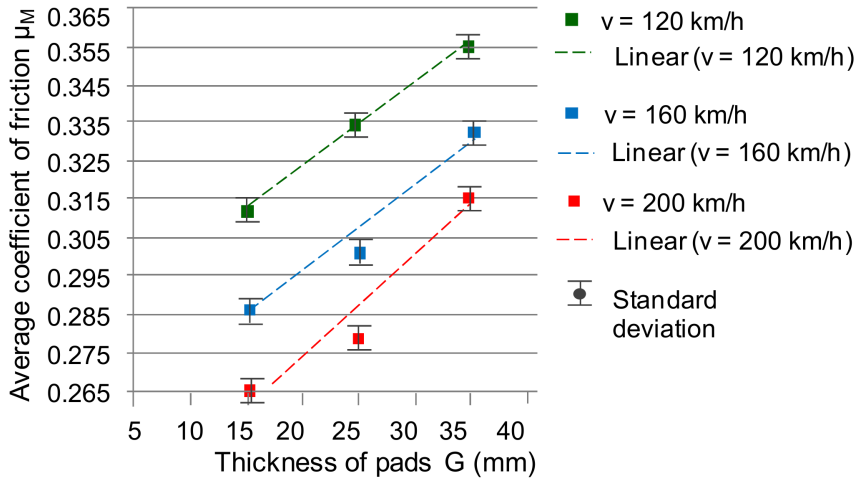

(b)

Figure 11. Dependence of the average coefficient of friction $\mu_{m}$ on the thickness of the friction linings for the speed at the beginning of braking: (a) $v=50$ and $80 \mathrm{~km} / \mathrm{h},(\mathbf{b}) v=120,160$ and $200 \mathrm{~km} / \mathrm{h}$.

The average coefficient of friction was approximated by a linear function, which is represented by the following relationships:

$$
\begin{aligned}
& \mu_{m}=7 \times 10^{-4} \mathrm{G}+0.34 ; \text { for } v=50 \mathrm{~km} / \mathrm{h} \\
& \mu_{m}=9 \times 10^{-4} \mathrm{G}+0.33 ; \text { for } v=80 \mathrm{~km} / \mathrm{h} \\
& \mu_{m}=21 \times 10^{-4} \mathrm{G}+0.28 ; \text { for } v=120 \mathrm{~km} / \mathrm{h} \\
& \mu_{m}=23 \times 10^{-4} \mathrm{G}+0.25 ; \text { for } v=160 \mathrm{~km} / \mathrm{h} \\
& \mu_{m}=26 \times 10^{-4} \mathrm{G}+0.22 ; \text { for } v=200 \mathrm{~km} / \mathrm{h}
\end{aligned}
$$

Due to the existence of a linear dependence (at low speeds during braking) or nonlinear (at high speeds during braking) between the thickness of the friction linings and the 
values of the measures, as well as the linear relationship for all speeds during braking of the average coefficient of friction on the lining thickness, the dependence was determined by the method of substituting two functions of the average coefficient of friction on the basis of registered vibrations. The general form of estimating the average value of the friction coefficient is presented in Equations (25) and (26). In the $A_{R M S}$ example, Equation (25) is calculated based on two linear functions, and Equation (26) is the result of combining a non-linear function with a linear function.

$$
\begin{gathered}
\left\{\begin{array}{l}
\mathrm{G}=\mathrm{a}_{1} \times \mathrm{A}_{\mathrm{RMS}}+b_{1} \\
\mu_{m}=\mathrm{a}_{2} \times \mathrm{G}+\mathrm{b}_{2}
\end{array}\right. \\
\mu_{m}=\mathrm{a}_{1} \times a_{2} \times \mathrm{A}_{\mathrm{RMS}}+a_{2} \times b_{1}+b_{2} \\
\text { for } v_{0}=50,80,120\left[\frac{\mathrm{km}}{\mathrm{h}}\right] \\
\left\{\begin{array}{l}
\mathrm{G}=\mathrm{c}_{1} \times \mathrm{A}_{\mathrm{RMS}}{ }^{d_{1}} \\
\mu_{m}=\mathrm{c}_{2} \times \mathrm{G}+\mathrm{d}_{2}
\end{array}\right. \\
\mu_{m}=\mathrm{c}_{1} \times c_{2} \times \mathrm{A}_{\mathrm{RMS}} \mathrm{d}_{1}+d_{2} \\
\text { for } v_{0}=160,200\left[\frac{\mathrm{km}}{\mathrm{h}}\right]
\end{gathered}
$$

where:

$a_{1}$-multiplier of the linear model of the friction lining thickness as a function of $\mathrm{A}_{\mathrm{RMS}}$ or $\mathrm{A}_{\text {AVERAGE }}$ for $v_{0}=50,80$ and $120 \mathrm{~km} / \mathrm{h}$;

$b_{1}$-free term of the linear model of friction lining thickness in the $\mathrm{A}_{\text {RMS }}$ or $\mathrm{A}_{\mathrm{AVERAGE}}$ function for $v_{0}=50,80$ and $120 \mathrm{~km} / \mathrm{h}$;

$c_{1}$-directional coefficient of the non-linear (power) model of the friction lining thickness as a function of $A_{\text {RMS }}$ or $A_{A V E R A G E}$ for $v_{0}=160$ and $200 \mathrm{~km} / \mathrm{h}$;

$d_{1}$-exponent of the non-linear model of friction lining thickness in the $A_{R M S}$ or $A_{A V E R A G E}$ function for $v_{0}=160$ and $200 \mathrm{~km} / \mathrm{h}$;

$a_{2}$-multiplier of the linear model of the average friction coefficient as a function of the friction lining thickness for $v_{0}=50,80$ and $120 \mathrm{~km} / \mathrm{h}$;

$b_{2}$-free term of the linear model of the average friction coefficient as a function of the friction lining thickness for $v_{0}=50,80$ and $120 \mathrm{~km} / \mathrm{h}$;

$c_{2}$-multiplier of the linear model of the average friction coefficient as a function of the friction lining thickness for $v_{0}=160$ and $200 \mathrm{~km} / \mathrm{h}$;

$d_{2}$-free term of the linear model of the average friction coefficient as a function of the friction lining thickness for $v_{0}=160$ and $200 \mathrm{~km} / \mathrm{h}$.

Based on the dependence on the wear of the friction linings as a function of the value of the vibration acceleration measures and the average coefficient of friction on the wear of the friction linings, as well as the Functions (25) and (26), the following relationships were determined to estimate the average value of the friction coefficient:

$$
\begin{gathered}
\mu_{m}=-0.0047 \times A_{\text {AVERAGE }}+0.386 ; \text { for } v=50 \mathrm{~km} / \mathrm{h} \\
\mu_{m}=-0.0029 \times A_{\text {AVERAGE }}+0.376 ; \text { for } v=80 \mathrm{~km} / \mathrm{h} \\
\mu_{m}=-0.0059 \times A_{\text {AVERAGE }}+0.394 ; \text { for } v=120 \mathrm{~km} / \mathrm{h} \\
\mu_{m}=0.56 \times A_{\text {AVERAGE }}-0.94+0.249 ; \text { for } v=160 \mathrm{~km} / \mathrm{h} \\
\mu_{m}=0.21 \times A_{\text {AVERAGE }}-0.46+0.222 ; \text { for } v=200 \mathrm{~km} / \mathrm{h}
\end{gathered}
$$

The results of the research showed that on the basis of the braking system vibration acceleration measures analyzed in this study, it is possible to both diagnose the condition of the brake, already described in [43], as well as to assess the braking process by determining the average coefficient of friction [44]. 
The relative percentage error in the representation of the regression model of the average coefficient of friction on the basis of the recorded signals of vibration accelerations during braking is approximately $1 \%$ at $v=50,80$ and $120 \mathrm{~km} / \mathrm{h}$. It occurs both with averaging the vibration acceleration signal with the $A_{R M S}$ effective value and with the $\mathrm{A}_{\text {AVERAGE }}$ value. During braking from $v=160 \mathrm{~km} / \mathrm{h}$, the error in estimating the average value of the coefficient of friction is about $4 \%$ for $A_{\text {RMS }}$ and $2.5 \%$ for $A_{A V E R A G E}$. Braking at $v=200 \mathrm{~km} / \mathrm{h}$ causes an error in the estimation of $6 \%$ for both the average and the effective value.

Figure 12 presents a graphic representation of the match of the regression model for estimating the value of the average coefficient of friction on the basis of the average value of the vibration acceleration of the friction linings.

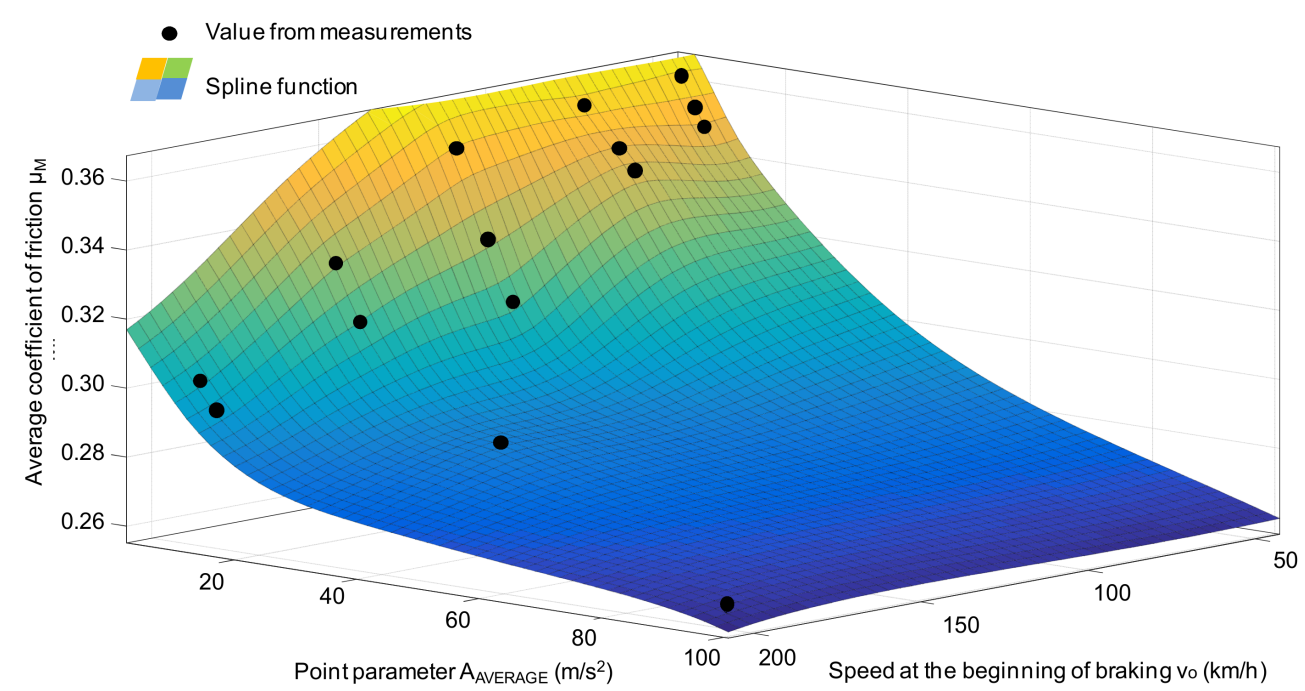

Figure 12. Dependence of the average coefficient of friction $\mu_{m}$ on the $A_{A V E R A G E}$ function and velocity $v_{0}$, obtained from the tests in relation to the regression model obtained from Equations (27)-(31) on the example of the spline function.

Based on the relationships (13)-(17) and (27)-(31), on the example of the average value of vibration accelerations, it is possible to develop a diagnostic algorithm for the simultaneous assessment of the brake friction material wear and determination of the average friction coefficient for the railway disc brake. For the selected speed at the beginning of braking, Figure 13 shows an algorithm which, in the three-state evaluation (serviceability, acceptability and limit condition), determines the wear range of the friction linings and the value of the average coefficient of friction.

The algorithm uses data from the measurement of vehicle speed and vibrations of the braking system, functions describing wear and the coefficient of friction. The wear assessment is performed in three ranges, i.e., for the thickness of the friction linings from 5 to $35 \mathrm{~mm}$, for the thickness of $5 \mathrm{~mm}$, and less than $5 \mathrm{~mm}$. For the average coefficient of friction, its value is estimated from 0.310 to 0.390 , as recommended in accordance with the UIC 541-3 sheet. Values equal to 0.390 and 0.310 are considered acceptable, while values lower than 0.310 are the limit value of this parameter. When the limit values for both the friction lining wear and the friction coefficient are reached, a message appears to the driver to send the vehicle for inspection. 


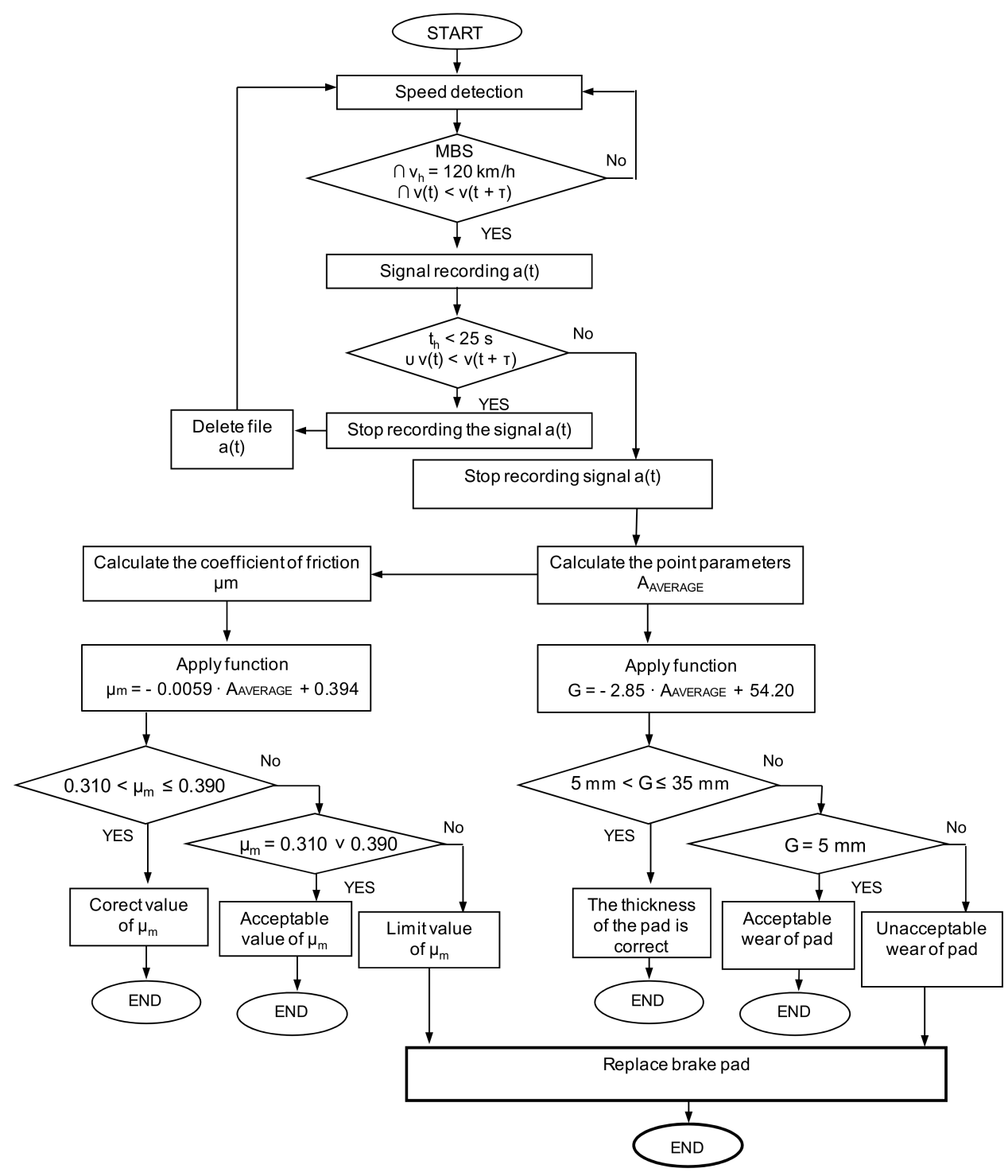

Figure 13. Algorithm of wear evaluation and estimation of the average coefficient of friction during braking at $v=120 \mathrm{~km} / \mathrm{h}$; MBS-perform service stopping braking, $\tau$-increase of the braking time.

5. Regression Model of Friction Lining Wear and $\mu_{m}$ Variability Based on the Analysis of Vibration Acceleration Signals in the Frequency Domain

Spectral analysis, allow identification of the wear of the friction linings with greater accuracy (higher value of the dynamics of changes than in the analysis in the amplitudes domain). Due to the dependence of the change in the brake friction coefficient on the wear of the friction material (Figure 10), the $\mu_{m}$ value on the basis of the vibrations generated by the friction linings during braking was estimated. The main purpose of the spectral analysis of vibration signals was to determine common frequency bands related to the change in the lining thickness during the operation of the brake system in a wide braking range (speed from 50 to $200 \mathrm{~km} / \mathrm{h}$ ). Then, from a given frequency band, the effective value of vibration accelerations was determined in accordance with the relationship (4), and the parameter of dynamics of changes in $\mathrm{dB}$ was checked, in accordance with the relationship (5). Figure 14 shows examples of amplitude spectra of vibration acceleration signals generated during braking by the friction linings.

The analysis of vibration acceleration signals in the spectral domain generated by the friction linings does not allow the finding of a common frequency band for all analyzed speeds and thicknesses of the friction linings. It is especially difficult when braking from 
low speeds (50 and $80 \mathrm{~km} / \mathrm{h}$ ). At these speeds, no increase in the RMS value from a given frequency band is observed with the wear of the brake components. For medium and high speeds during braking $(120,160$ and $200 \mathrm{~km} / \mathrm{h}$ ), it is possible to determine the frequency bands in which the $A_{\text {RMS }}$ changes depend on the friction lining wear (Table 3 ).

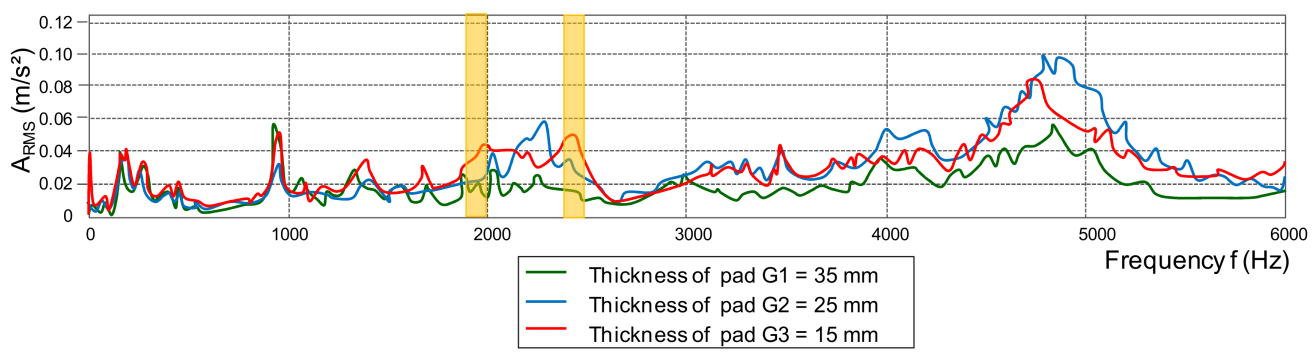

(a)

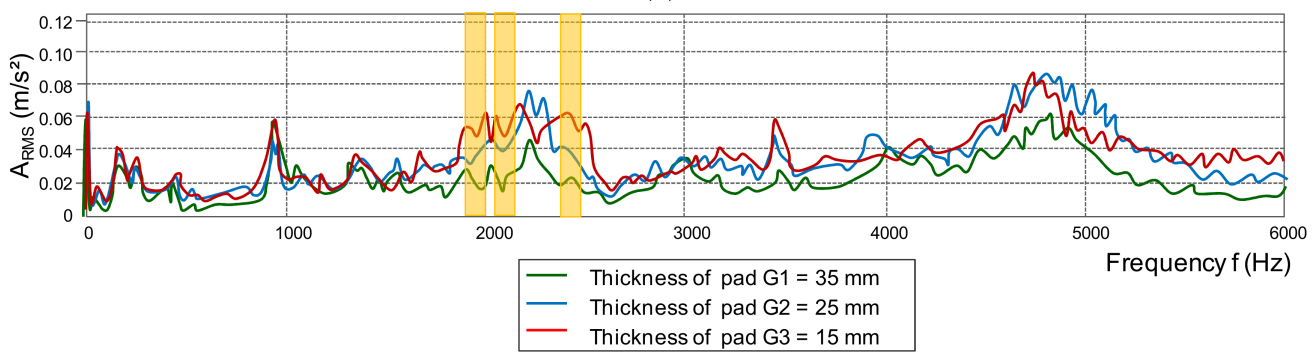

(b)

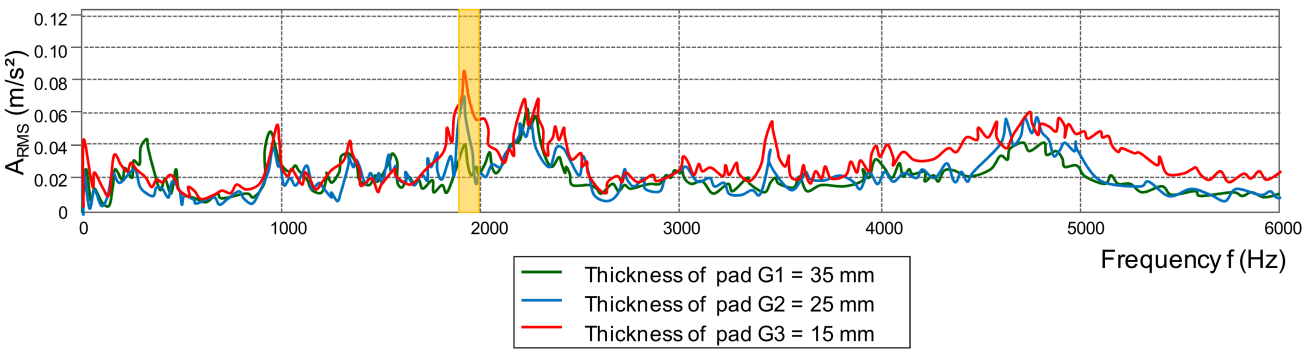

(c)

Figure 14. Dependence of the amplitude of vibration accelerations on the frequency for different friction lining thicknesses when braking from the speed: (a) $v=120 \mathrm{~km} / \mathrm{h}$, (b) $v=160 \mathrm{~km} / \mathrm{h}$, (c) $v=200 \mathrm{~km} / \mathrm{h}$.

For the common frequency band of 1950-2000 Hz, the vibration acceleration of the friction linings, taking into account both the three braking speeds $(120,160$ and $200 \mathrm{~km} / \mathrm{h}$ ) and the wear of the friction linings, the $A_{\mathrm{RMS}}$ exchange characteristics were determined (Figure 15).

For diagnostic purposes, the dependence of the friction lining thickness on the effective value of vibration acceleration was determined (Figure 15b). The dependence was approximated by a linear function in order to derive the following linear regression models of friction lining wear assessment:

$$
\begin{aligned}
& G=-72.7 \times A_{R M S}+59.1 ; \text { for } v=120 \mathrm{~km} / \mathrm{h} \\
& G=-40.4 \times A_{R M S}+50.2 ; \text { for } v=160 \mathrm{~km} / \mathrm{h} \\
& G=-22.9 \times A_{R M S}+53.9 ; \text { for } v=200 \mathrm{~km} / \mathrm{h}
\end{aligned}
$$

Then, regressive linear models of changes in the average coefficient of friction as a function of the thickness of the friction material presented in Figure $11 \mathrm{~b}$ and described with the dependencies (22)-(24) were used. By substituting two linear functions $G=f\left(A_{R M S}\right)$ and $\mu_{m}=\mathrm{f}(\mathrm{G})$, in accordance with the general Equation (25), linear regression models of the 
average friction coefficient were determined based on the vibrations of the friction linings subjected to spectral analysis in the $1950-2000 \mathrm{~Hz}$ frequency band.

$$
\begin{aligned}
& \mu_{m}=-0.153 \times \mathrm{A}_{\mathrm{RMS}}+0.404 ; \text { for } v=120 \mathrm{~km} / \mathrm{h} \\
& \mu_{m}=-0.097 \times \mathrm{A}_{\mathrm{RMS}}+0.369 ; \text { for } v=160 \mathrm{~km} / \mathrm{h} \\
& \mu_{m}=-0.153 \times \mathrm{A}_{\mathrm{RMS}}+0.404 ; \text { for } v=120 \mathrm{~km} / \mathrm{h}
\end{aligned}
$$

The relative percentage error in the representation of the regression model of the average coefficient of friction on the basis of the recorded signals of vibration acceleration during braking does not exceed 3\% for the analyzed speeds at the beginning of braking $(v=120,160$ and $200 \mathrm{~km} / \mathrm{h}$ ). It should be emphasized that the use of the spectral analysis with subsequent band filtering means that the diagnostic models in the assessment of friction lining wear and estimating the friction coefficient values are twice as accurate in relation to the analysis in the amplitudes domain. A significant drawback of spectral analysis is the difficulty of identifying a common frequency band for a wide range of braking speeds. The use of a common bandpass filter is possible only at medium and high speeds, while at low speeds $(v=50$ and $80 \mathrm{~km} / \mathrm{h})$ the effective values of vibration acceleration are comparable with the values derived from the amplitude analysis. Figure 16 shows the algorithm (for a selected speed $(200 \mathrm{~km} / \mathrm{h}$ ) to assess the wear of friction linings and to evaluate the braking process.

\begin{tabular}{|c|c|c|c|c|}
\hline \multirow{2}{*}{ Frequency $\mathrm{Hz}$} & \multicolumn{3}{|c|}{$\mathrm{A}_{\text {RMS Value } \mathrm{m} / \mathrm{s}^{2}}$} & \multirow{2}{*}{$\begin{array}{l}\text { Dynamics of } \\
\text { Change dB }\end{array}$} \\
\hline & $\begin{array}{l}\text { Cladding Thickness } \\
\mathrm{G}_{1}=35 \mathrm{~mm}\end{array}$ & $\begin{array}{l}\text { Cladding Thickness } \\
\mathrm{G}_{2}=25 \mathrm{~mm}\end{array}$ & $\begin{array}{l}\text { Cladding Thickness } \\
\mathrm{G}_{3}=15 \mathrm{~mm}\end{array}$ & \\
\hline \multicolumn{5}{|c|}{ Braking start at $v=120 \mathrm{~km} / \mathrm{h}$} \\
\hline 1950-2000 & 0.33 & 0.46 & 0.61 & 5.20 \\
\hline $2450-2500$ & 0.29 & 0.48 & 0.64 & 7.00 \\
\hline \multicolumn{5}{|c|}{ Braking start at $v=160 \mathrm{~km} / \mathrm{h}$} \\
\hline 1950-2000 & 0.39 & 0.59 & 0.88 & 7.08 \\
\hline $2050-2100$ & 0.46 & 0.75 & 0.89 & 5.81 \\
\hline $2450-2500$ & 0.38 & 0.54 & 0.99 & 8.34 \\
\hline \multicolumn{5}{|c|}{ Braking start at $v=200 \mathrm{~km} / \mathrm{h}$} \\
\hline 1950-2000 & 0.78 & 1.35 & 1.64 & 6.27 \\
\hline $3400-3450$ & 0.38 & 0.66 & 0.98 & 8.19 \\
\hline $5050-5100$ & 0.49 & 0.63 & 1.02 & 6.41 \\
\hline $5300-5350$ & 0.35 & 0.39 & 0.75 & 6.65 \\
\hline
\end{tabular}

Table 3. A $A_{R M S}$ values from the frequency bands of the vibration acceleration of the friction linings depending on the speed of braking and the wear of the friction linings along with the dynamics of changes.

In the first stage of the algorithm, the analysis of vibration acceleration signals for low and medium speeds during braking is carried out, using measures and spectral analysis at speeds above $120 \mathrm{~km} / \mathrm{h}$. The algorithm presented in Figure 16 is a procedure that allows the determination of both the thickness of the friction linings and the average coefficient of friction on the basis of the spectral analysis. The value of the thickness of the friction linings and the value of the average coefficient of friction with the imposed tolerance of the average coefficient of friction are compliant with the UIC 541-3 sheet. For the algorithm presented in Figure 13, based on the analysis in the amplitudes domain, greater accuracy was obtained in mapping the regression models.

The tests were carried out on a certified stand for testing railway disc brakes in the 1:1 scale. Considering the fact that research on real objects was carried out, more attention was paid to the results of vibroacoustic tests, which can be directly used in railways. Hence, the obtained results were assessed quantitatively. Algorithms for assessing the condition of friction linings were proposed, i.e., for the assessment of wear and for the assessment of the braking process. The developed test methodology with vibration transducers can be directly applied in a real object, i.e., on a disc brake of a passenger car. 


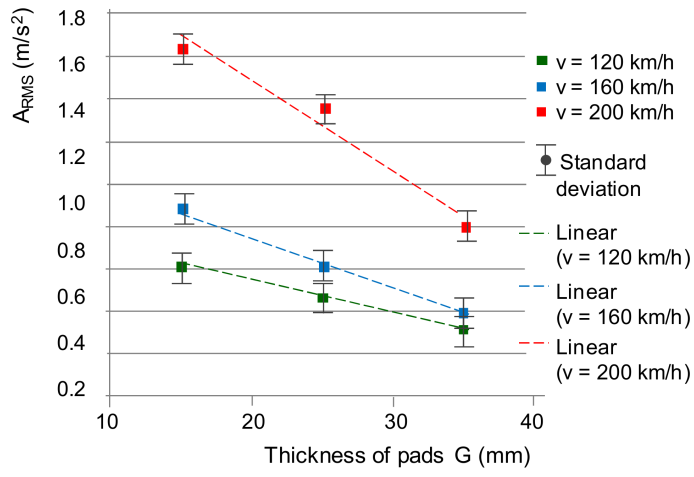

(a)

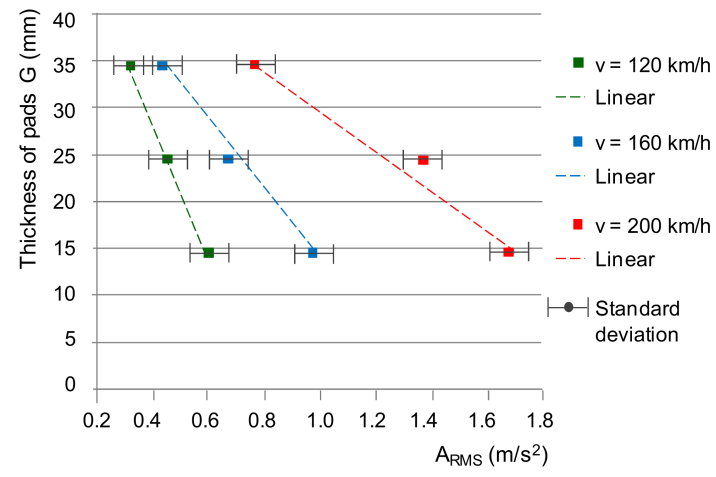

(b)

Figure 15. Characteristics of changes: (a) $A_{R M S}=f(G),(b) G=f\left(A_{R M S}\right)$ for three braking speeds in the 1950-2000 Hz frequency band.

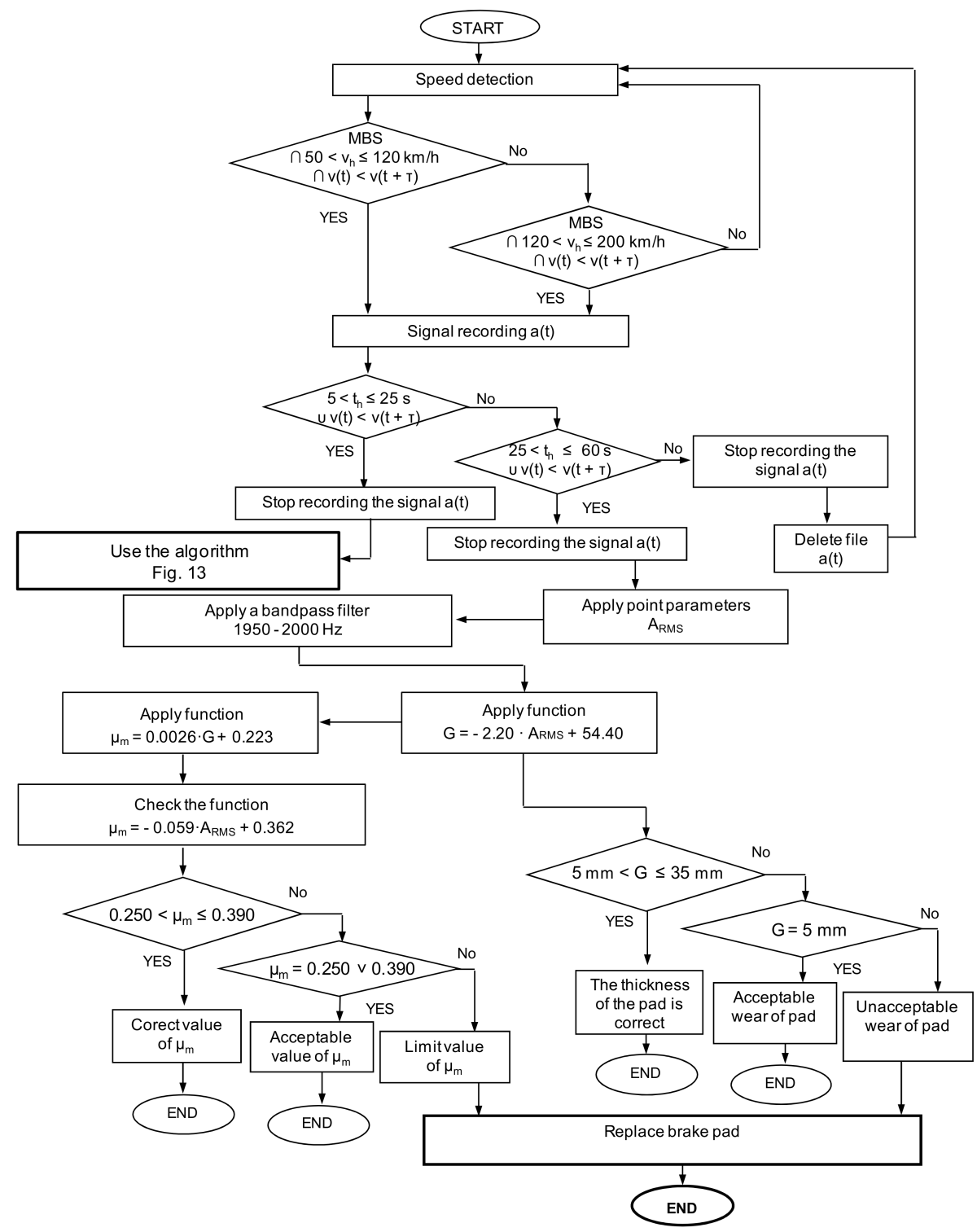

Figure 16. Algorithm of wear assessment and estimation of the average coefficient of friction during braking, for the speed $v=200 \mathrm{~km} / \mathrm{h}$ using the spectral analysis; MBS-perform service stopping braking, $\tau$-increase of the braking time. 


\section{Conclusions}

Based on the test results, it is possible to use the vibroacoustic diagnostics (WA) more widely and the following conclusions can be drawn:

- Besides the assessment of the technical object condition, the changes in the average coefficient of friction as a function of the braking speed can be determined. This is due to the strong dependence of the diagnostic parameter on wear expressed by the dynamics of changes, exceeding $6 \mathrm{~dB}$, as well as the dependence of the average coefficient of friction on the speed and friction linings wear. The combination of both functions enables the determination of linear (at low speeds) and non-linear (at higher braking speeds) regression models to estimate the value of the average coefficient of friction;

- The error in matching the regression model of the average coefficient of friction on the basis of the determined measures during braking only at some speeds of the beginning of braking reaches the value of $6 \%$;

- It is not possible to find a common frequency band for a wide range of braking speeds (from 50 to $200 \mathrm{~km} / \mathrm{h}$ ). The common frequency band in the range of $1950-2000 \mathrm{~Hz}$ enables the determination of the $A_{\text {RMS }}$ dependence from the band for three cases of the friction material condition, and for medium and high speed when braking with the dynamics of changes exceeding $6 \mathrm{~dB}$;

- The error of adjusting the results of operational tests to the values determined from the regression linear models of the coefficient of friction, determined with the relative percentage error, does not exceed $1 \%$ for $v=120 \mathrm{~km} / \mathrm{h}, 3 \%$ for $v=160 \mathrm{~km} / \mathrm{h}$, and $1.5 \%$ for $v=200 \mathrm{~km} / \mathrm{h}$;

- For amplitude analyses, the error of fitting the regression model to the test results exceeds $6 \%$ for $v=200 \mathrm{~km} / \mathrm{h}, 2.4-3.7 \%$ for $v=160 \mathrm{~km} / \mathrm{h}$, depending on the measure used, and about $1-1.5 \%$ for the average $(120 \mathrm{~km} / \mathrm{h})$ and low braking speeds (50-80 km/h).

It should be emphasized that the use of vibration diagnostics to assess the wear of the friction material on the basis of amplitude analysis (for low speeds at the beginning of braking) and spectral analysis (for high speeds at the beginning of braking) additionally enables the assessment of the braking process in terms of changes in the average friction coefficient. Due to the imposed wear limits of the friction material and the tolerance of the average coefficient of friction, it is possible to apply simple algorithms based on measuring the speed of the rail vehicle and vibrations from the braking system. Then, after reaching the limit wear of the friction linings (below $5 \mathrm{~mm}$ ) or the value of $\mu_{m}$ exceeding the lower or upper tolerance, as a result of, i.e., damage or burning of the friction surface of the lining, a message appears on the control panel that the linings need to be replaced without visual inspection of the brake system.

Author Contributions: Conceptualization, W.S. and D.U.; methodology, W.S.; software, J.K.; validation, W.S., D.U. and J.K.; formal analysis, A.M.-G.; investigation, W.S.; resources, W.S. and D.U.; data curation, J.K.; writing — original draft preparation, W.S. and D.U.; writing-review and editing, W.S. and D.U.; visualization, W.S. and D.U.; supervision, A.M.-G.; project administration, W.S.; funding acquisition, A.M.-G. All authors have read and agreed to the published version of the manuscript.

Funding: This research was funded by Poznan University of Technology, grant number 0416/SBAD/0002.

Institutional Review Board Statement: Not applicable.

Informed Consent Statement: Not applicable.

Data Availability Statement: The data presented in this study are available on request from the corresponding author.

Conflicts of Interest: The authors declare no conflict of interest. 


\section{References}

1. Kinkaid, N.M.; O’Reilly, O.M.; Papadopoulos, P. Automotive disc brake squeal. J. Sound Vib. 2003, 267, 105-166. [CrossRef]

2. Kruse, S.; Tiedemann, M.; Zeumer, B.; Reuss, P.; Hetzler, H.; Hoffmann, N. The influence on joints on friction induced vibration in brake squeal. J. Sound Vib. 2015, 340, 239-252. [CrossRef]

3. Lang, A.M.; Smales, H. An Approach to the Solution of Disc Brake Vibration Problems, in Braking of Road Vehicles; Automobile Division of the Institution of Mechanical Engineers, Mechanical Engineering Publications Limited: Suffolk, UK, 1993; pp. $223-231$.

4. Nosal, S. Tribologia. Wprowadzenie do Zagadnień Tarcia, Zużywania i Smarowania; Wydawnictwo Politechniki Poznańskiej: Poznań, Poland, 2012.

5. Rudolph, M.; Popp, K. Brake squeal. In Detection, Utilization and Avoidance of Nonlinear Dynamical Effects in Engineering Applications; Final Report of a Join Research Sponsored by the German Federal Ministry of Education and Research; Popp, K., Ed.; Shaker: Aachen, Germany, 2001; pp. 197-225.

6. Sinclair, D. Frictional vibrations. Trans. Am. Soc. Mech. Eng. J. Appl. Mech. 1955, 77, 207-213. [CrossRef]

7. Ścieszka, S.F. Hamulce Cierne. Zagadnienia Materiałowe, Konstrukcyjne i Tribologiczne; Wydawnictwo Gliwice: Radom, Poland, 1998; p. 15.

8. Triches, M.; Gerges, S.N.Y.; Jordan, R. Analysys of Brake Squale Noise Using Finite Element Method: A Parametric Study; Federal University of Santa Caterina: Florianópolis, Brazil, 2007.

9. Bowden, F.P.; Leben, L. The nature of sliding and the analysis of friction. In Royal Society of London Proceedings Series A Mathematics Physics and Engineering Science; The Royal Society Publishing, Laboratory of Physical Chemistry: Cambrige, UK, 1939; Volume 169, pp. 371-391.

10. Brooks, P.C.; Crolla, D.A.; Lang, A.M.; Schafer, D.R. Eigenvalue sensitivity analysis applied to disc brake squeal. In Braking of Road Vehicles, Institution of Mechanical Engineers; Mechanical Engineering Publications Limited: Bury St. Edmunds, UK, 1993; pp. 135-143.

11. Sawczuk, W.; Szymański, G.M. Diagnostics of the railway friction disc brake based on the analysis of the vibration signals in terms of resonant frequency. Arch. Appl. Mech. 2016, 86, 1-15. [CrossRef]

12. Sawczuk, W.; Tomaszewski, F. Application of FFT Fast Fourier Transform to the vibration signal generated by the disc brake to assess the wear of friction pads during braking with the constant braking power. Arch. Automtive Eng. 2013, 61, 43-52.

13. Sawczuk, W. Application of vibroacoustic diagnostics to evaluation of wear of friction pads rail brake disc. Maint. Reliab. 2016, 18, 565-571. [CrossRef]

14. Sawczuk, W. Evaluation of the wear of friction pads railway disc brake using selected point parameters of vibrations signal generated by the disc brake. Diagn. Appl. Struct. Health Usage Cond. Monit. 2014, 15, 33-38.

15. Sinclair, D. Acoustic emission analysis during fatigue crack growth in steel. Mater. Sci. Eng. 1977, 28, 263-273. [CrossRef]

16. Sawczuk, W. Application of selected frequency characteristics of vibration signal for the evaluation of the braking process for railway disc brake. Diagnostyka 2015, 16, 33-38.

17. Fosberry, R.A.C.; Holubecki, A. Disc Brake Squeal: Its Mechanism and Suppression; Technical Report; Motor Industry Research Association: Warwickshire, UK, 1961; Volume 2, pp. 34-36.

18. Earles, S.W.E.; Chambers, P.W. Disc brake squeal noise generation: Predictiong its dependency on system parameters including damping. Int. J. Veh. Des. 1987, 8, 538-552.

19. Haneef, M.D.; Randall, R.B.; Smith, W.A.; Peng, Z. Vibration and wear prediction analysis of IC engine bearings by numerical simulation. Wear 2017, 384-385, 15-27. [CrossRef]

20. Spurr, R.T. A theory of brake squeal, Proceedings of the Automobile Division. Inst. Mech. Eng. 1961, 1, 33-52.

21. Millner, N. An Analysis of Disc Brake Squeal; Technical Report 780332; SAE Warrendale: Warrendale, PA, USA, 1978.

22. Rudolph, M.; Popp, K. Friction induced brake vibrations. In CD-ROM Proceedings of DETC'01, DETC2001/VIB-21509; ASME: Pittsburgh, PA, USA, 2001; pp. 1-10.

23. Gill, A. Optimisation of the technical object maintenance system taking account of risk analysis results. Maint. Reliab. 2017, 19, 420-431. [CrossRef]

24. Gill, A.; Smoczyński, P. Layered model for convenient designing of safety system upgrades in railways. Saf. Sci. 2018, 110, 168-176. [CrossRef]

25. European Standard EN 14535-1:2005. Railway Applications—Brake Discs for Railway Rolling Stock—Part 1: Brake Discs Pressed or Shrunk onto the Axle or Drive Shaft, Dimensions and Quality Requirements; British-Adopted European Standard: London, UK, 2005; pp. 22-23.

26. Brakes-Disc Brakes and Their Application-General Conditions for the Approval of Brake Pads, 7th ed.; Appendix to UIC Code 541-3; International Union of Railways: Paris, France, 2010.

27. Szymański, G.M.; Josko, M.; Tomaszewski, F.; Filipiak, R. Application of time-frequency analysis to the evaluation of the condition of car suspension. Mech. Syst. Signal Process. 2015, 58-59, 298-308. [CrossRef]

28. Szymański, G.M.; Tomaszewski, F. Diagnostics of automatic compensators of valve clearance in combustion engine with the use of vibration signal. Mech. Syst. Signal Process. 2016, 68-69, 479-490. [CrossRef]

29. Antoni, J.; Griffaton, J.; André, H.; Avendaño-Valencia, L.D.; Bonnardot, F.; Cardona-Morales, O.; Castellanos-Dominguez, G.; Daga, A.P.; Leclère, Q.; Vicuña, C.M.; et al. Feedback on the Surveillance 8 challenge: Vibration-based diagnosis of a Safran aircraft engine. Mech. Syst. Signal Process. 2017, 97, 112-144. [CrossRef] 
30. Balicki, W. Potrzeby i sposoby diagnozowania lotniczych silników turbinowych. Pr. Inst. Lotnictwa 2009, 199, 109-116.

31. Chen, J.; Randall, R.B. Intelligent diagnosis of Bering knock faults in internal combustion engines Rusing vibration simulation. Mech. Mach. Theory 2016, 104, 161-176. [CrossRef]

32. Glowacz, A. Ventilation Diagnosis of Angle Grinder Using Thermal Imaging. Sensors 2021, 21, 2853. [CrossRef] [PubMed]

33. Glowacz, A. Fault diagnosis of electric impact drills using thermal imaging. Measurement 2021, 171, 108815. [CrossRef]

34. Glowacz, A. Fault diagnostics of acoustic signals of loaded synchronous motor using SMOFS-25-EXPANDED and selected classifiers. Teh. Vjesn. Tech. Gaz. 2016, 23, 1365-1372. [CrossRef]

35. Mironov, A.; Doronkin, P.; Priklonsky, A.; Kabashkin, I. The Role of Advanced Technologies of Vibration Diagnostics to Provide Efficiency of Helicopter Life Cycle. Procedia Eng. 2017, 178, 96-106. [CrossRef]

36. Moosavian, A.; Najafi, G.; Ghobadian, B.; Mirsalim, M. The effect of piston scratching fault on the vibration behavior of an IC engine. Appl. Acoust. 2017, 126, 91-100. [CrossRef]

37. Sawczuk, W.; Merkisz-Guranowska, A.; Rilo Cañás, A. Assessment of disc brake vibration in rail vehicle operation on the basis of brake stand. Maint. Reliab. 2021, 23, 221-230.

38. Gryboś, R.; Sawczuk, W. Drgania Maszyn; Wydawnictwo Politechniki Śląskiej: Gliwice, Poland, 2009.

39. Abbasi, S.; Wahlström, J.; Olander, L.; Larsson, C.; Olofsson, U.; Sellgren, U. A study of airborne wear particles generated from organic railway brake pads and brake disc. Wear 2011, 273, 93-99. [CrossRef]

40. Wojciechowski, M.; Sawczuk, W. Koncepcja diagnostyki samochodowego hamulca tarczowego metodą drganiową. Logistyka 2014, 3, 6729-6738.

41. Analytical model coefficient of friction (COF) of rail disc brake on the basis of multi-phase stationary tests. Maint. Reliab. 2018, 20, $57-67$.

42. Segal, L. Diagnostic method for vehicle brakes. NDT E Int. 1999, 32, 369-373. [CrossRef]

43. Sawczuk, W. Analiza statystyczna sygnałów drganiowych generowanych przez mechanizm dźwigniowy hamulca tarczowego w czasie hamowania. Autobusy Tech. Eksploat. Syst. Transp. 2013, 3, 441-449.

44. Sawczuk, W. The Application of Vibration Accelerations in the Assessment of Average Friction Coefficient of a Railway Brake Disc. Meas. Sci. Rev. 2017, 17, 125-134. [CrossRef] 